NBER WORKING PAPER SERIES

\title{
SIMPLIFYING TAX INCENTIVES AND AID FOR COLLEGE: PROGRESS AND PROSPECTS
}

\author{
Susan Dynarski \\ Judith Scott-Clayton \\ Mark Wiederspan \\ Working Paper 18707 \\ http://www.nber.org/papers/w18707 \\ NATIONAL BUREAU OF ECONOMIC RESEARCH \\ 1050 Massachusetts Avenue \\ Cambridge, MA 02138 \\ January 2013
}

This paper is forthcoming in Tax Policy and the Economy, vol. 27. We thank Monica Bhatt and Dyuti Bhattacharya for excellent research assistance. Jeffrey Brown provided helpful comments. All errors and opinions are our own. The views expressed herein are those of the authors and do not necessarily reflect the views of the National Bureau of Economic Research.

NBER working papers are circulated for discussion and comment purposes. They have not been peerreviewed or been subject to the review by the NBER Board of Directors that accompanies official NBER publications.

(C) 2013 by Susan Dynarski, Judith Scott-Clayton, and Mark Wiederspan. All rights reserved. Short sections of text, not to exceed two paragraphs, may be quoted without explicit permission provided that full credit, including $(\mathcal{C}$ notice, is given to the source. 
Simplifying Tax Incentives and Aid for College: Progress and Prospects

Susan Dynarski, Judith Scott-Clayton, and Mark Wiederspan

NBER Working Paper No. 18707

January 2013

JEL No. I22

\begin{abstract}
$\underline{\text { ABSTRACT }}$
The application for federal student aid is longer than the tax returns filled out by the majority of US households. Research suggests that complexity in the aid process undermines its effectiveness in inducing more students into college. In 2008, an article in this journal showed that most of the data items in the aid application did not affect the distribution of aid, and that the much shorter set of variables available in IRS data could be used to closely replicate the existing distribution of aid. This added momentum to a period of discussion and activity around simplification in Congress and the US Department of Education. In this article, we provide a five-year retrospective of what's changed in the aid application process, what hasn't, and the possibilities for future reform. While there has been some streamlining in the process of applying for aid, it has fallen far short of its goals. Two dozen questions were removed from the aid application and a dozen added, reducing the number of questions from 127 to 116. Funding for college has also been complicated by the growth of a parallel system for aid: the tax system. A massive expansion in federal tax incentives for college, in particular the American Opportunity Tax Credit, has led to millions of households completing paperwork for both the IRS and the US Department of Education in order to qualify for college funding.
\end{abstract}

Susan Dynarski

University of Michigan

Weill Hall

735 South State Street

Ann Arbor, MI 48109-3091

and NBER

dynarski@umich.edu

Judith Scott-Clayton

Teachers College

Columbia University

525 W.120th Street, Box 174

New York, NY 10027

and NBER

scott-clayton@tc.columbia.edu
Mark Wiederspan

University of Michigan

School of Education

610 East University Avenue

Ann Arbor, Michigan 48109-1259

mwieders@umich.edu 


\section{Introduction}

The application for federal aid for college, at 116 questions, is longer than the tax return completed by most US households. A long-standing theoretical and experimental literature suggests that seemingly minor differences in program design can have profound impacts upon decision-making (Kahneman and Tversky, 2000). A burgeoning empirical literature has demonstrated that these predictions hold in real-life situations such as saving for retirement (Madrian and Shea, 2001). Empirical patterns in the behavioral impact of student aid have supported the hypothesis that complexity in the aid system undermines its efficacy: simple aid programs have a robust impact on college attendance, while traditional forms of student aid (which require a FAFSA) do not (Dynarski and Scott-Clayton, 2006, 2008). A recent field experiment directly tested this hypothesis by randomly assigning families to a radically simplified aid application process (Bettinger et al., 2012). The results were striking: a simplified aid application produced substantial increases in college attendance - comparable to that induced by offering an applicant many more thousands of dollars in in grant aid.

Five years ago, we published in this journal an analysis of complexity in the aid system. Over the next few years, complexity in the aid system drew the attention of the media, advocacy groups, presidential candidates, the National Economic Council and the Council of Economic Advisers. A flurry of legislative and agency activity around aid simplification followed. There also ensued a significant expansion in the scope of tax benefits for college students, with annual expenditures for the education tax credits reaching $\$ 18$ billion. Eighteen million households now receive education tax benefits of some type, while 13 million receive traditional student aid. As a result, college students and their families now face two bureaucracies when trying to understand and apply for aid for college: the Internal Revenue Service and the US Department of Education (ED).

In this paper, we describe the array of federal subsidies for college students that are delivered through the tax system and the traditional aid programs. We review the evidence on the effectiveness of these programs in increasing the accumulation of human capital. And we provide a quantitative analysis of the plausibility of using IRS data alone to calculate eligibility for the traditional aid programs, thereby eliminating the need for a separate application for traditional student 
aid. This analysis updates that of Dynarski and Scott-Clayton (2008) with more recent data on aid receipt. This paper expands upon the analysis of Dynarski and Wiederspan (2012) by including part-time students, who comprise an increasing share of college enrollment, as well as examining how aid simplification could affect programs other than the Pell Grant.

The paper is structured as follows. In Section 2 we provide a broad overview of the two systems that subsidize college students in the US. We then turn to a more detailed description of the tax expenditures for college, the evidence on their efficacy, and critiques of their administration. In Section 4, we provide an analogous description of the traditional aid programs. We then turn to a discussion of policy efforts to simplify and streamline these systems. In Section 7 we discuss the feasibility of dividing labor between the two agencies that subsidize college students, with IRS collecting the financial data and ED delivering aid itself. We provide a quantitative analysis of the effect on the distribution of traditional aid of eliminating the aid application, using only IRS data to assign aid.

\section{Overview of Federal Funding for College Students}

In Table 1, we list the major programs that subsidize college costs for college students, for fiscal year 2010 (U.S. Government Accountability Office, 2011; Ackerman et al., 2011; College Board, 2011). ${ }^{1}$ The federal loan programs and the grant programs are the two largest sources of aid for college, subsidizing in recent years about 13 million students annually. Grants represented $\$ 49$ billion in 2010, with the Pell accounting for $\$ 35$ billion of this total and education grants for military service representing $\$ 12$ billion. In 2010, $\$ 104$ billion was disbursed through the federal loan programs. The cost of these loans is well below this figure, of course, since most will be repaid, unlike the grants.

In addition to the traditional aid programs, the tax system now delivers subsidies to college students and their families, to the tune of $\$ 29$ billion annually. The tax system subsidizes the families of future college students through the Coverdell and 529 programs, tax-advantaged savings plans authorized by the federal and state governments, respectively. The federal and state

\footnotetext{
${ }^{1}$ Appendix Table A1 provides a brief description of the programs we discuss in this paper.
} 
tax systems subsidize current college students and their families through tax credits (the federal American Opportunity Tax Credit, Lifetime Learning Credit and Hope Credit, plus a few state credits), a deduction for tuition costs, and a dependent exemption for students aged 19 to 23 . This latter provision also extends a family's eligibility for the Earned Income Tax Credit. Finally, the tax code subsidizes former college students with a deduction for interest paid on student loans. In 2010, 18 million tax filers benefited from one of the education tax programs (U.S. Government Accountability Office, 2012).

\section{Tax Expenditures for College Students}

Tax breaks for private spending on education have been a contentious topic for decades (Moynihan, 1978; Silliman, 2011). Private school associations and parents of children in private schools lobbied for a tax deduction for private school tuition (see Samwick (2012) of this volume for an analysis of one such proposal). Opponents have viewed this as a back door to government funding to religious

schools. Tuition deductions and credits were repeatedly proposed and repeatedly defeated. Several of the major changes in postsecondary policy were conceived as political responses to pressure to institute a private school tax break for middle-income constituents. Both the Guaranteed Student Loan (introduced in 1965, as part of the Higher Education Act) and the Middle Income Student Assistance Act (1978), which extended Title IV aid to middle and upper-income families, emerge d during battles over a tuition tax credit (Hearn, 2001).

There are more than a dozen federal provisions that provide tax advantages for those saving or paying for college, plus a number of scattered state programs. There still is no federal tax credit or deduction for the tuition costs of elementary or secondary school students.

\subsection{Tax Credits}

In 1996 Bill Clinton, then a candidate for the presidency, proposed a tax credit for the first two years of college costs. After Clinton's election, this proposal took shape as the Hope and Lifetime Learning Credits, introduced in 1997. The Hope and LLC allowed families of college students to offset their educational costs with tax benefits of up to $\$ 1,500$ a year. Tuition and required fees 
counted toward allowable expenses for both credits, with any grant aid deducted from allowable expenses. At its inception, the Hope Credit refunded $100 \%$ of the first $\$ 1,000$ of eligible expenses and $50 \%$ of up to $\$ 2000$ in remaining expenses. The LLC refunded $20 \%$ of the first $\$ 5,000$. The Hope Credit was limited to the first two years of college, while the LLC applied to any level of postsecondary education. When introduced, the Hope and LLC phased out between AGIs of $\$ 80,000$ and $\$ 100,000$ (\$40,000 and $\$ 50,000$ for single filers). Both credits were non-refundable (Kane, 1999).

The benefits of the Hope and LLC accrued largely to middle- and high-income families (greater than \$50,000) (Long, 2004). At very low AGIs (below \$10,000), families did not qualify for the credits because they had insufficient tax liability (and the credits were not refundable). Even for those with higher AGIs, the value of the credits could be limited by the definition of allowable expenses, which consisted only of tuition and fees. A typical, low-income student attending a community college with average tuition and fees of $\$ 2,439$ in 2010 (Institute of Education Sciences, 2011) and receiving the average Pell Grant of $\$ 3,416$ (U.S. Department of Education, 2012a) would have had no expenses eligible for Hope or LLC. For a middle-income student attending a more expensive private college and not receiving any grant aid, allowable expenses would generate the maximum tax credit.

The tax credits are received after a family files their taxes and documents their postsecondary expenses for a given year. This means they may be delivered more than a year after a tuition bill is paid (e.g., if tuition is paid in January of 2012 and the credit is claimed when the family files in April 2013).

The credits remained largely unchanged for 10 years, with minor tweaks to their maximum values and AGI phase-out ranges. By 2008, Hope refunded $100 \%$ of the first $\$ 1,200$ of expenses and $50 \%$ of the next $\$ 1,200$, for a maximum value of $\$ 1,800$. The LLC had a maximum value of $\$ 2,000$, refunding $20 \%$ of the first $\$ 10,000$ of eligible expenses (Crandall-Hollick, 2012). The phaseout ranges on both credits had increased to $\$ 96,000$ and $\$ 116,000$ ( $\$ 48,000$ to $\$ 58,000$ for a single filer), respectively. The number of households receiving the credits rose by more than half, from about 4.5 million filers in 1998 to 7.5 million in 2008 . The credits totaled $\$ 7.6$ billion in the 
2008 tax year.

Responding to critiques that the HOPE and LLC were of limited benefit to low-income families, presidential candidate Barack Obama proposed a tax credit that would cover a broader range of educational expenses than the Hope Credit, and would be partially refundable for families with zero tax liability. This proposal took form in 2009 as the American Opportunity Tax Credit, a renamed and modified version of the Hope credit. The American Opportunity Tax Credit (AOTC) allows individuals to reduce their federal income taxes by up to $\$ 2,500$ per eligible college student. AOTC was created as part of the American Recovery and Reinvestment Act of 2009 and temporarily replaced the HOPE Credit for 2009 and 2010. AOTC was extended for 2011 and 2012 by the Tax Relief Unemployment Insurance Reauthorization and the Job Creation Act of 2010. Currently AOTC is set to expire by the end of 2012. Should AOTC not be extended by Congress for 2013, AOTC will be replaced by the Hope Credit.

The maximum benefit for the AOTC was set at $\$ 2,500$, with $\$ 1,000$ of that amount refundable. All of the first $\$ 2,000$ in qualifying expenses is eligible for the credit, and $25 \%$ of an additional $\$ 2,000$. Eligible expenses include course-related books and supplies. This allows students attending low-tuition public institutions to access more of the credit. Students are allowed to claim the credit for four years of undergraduate education (unlike Hope, which was limited to 2 years). Like the Hope Credit, the AOTC is available for all eligible students in the household; by contrast, only one Lifetime Learning Credit may be claimed per household (Department of the Treasury, Internal Revenue Service, 2011).

With the introduction of the AOTC, spending on the tax credits rose sharply. In 2010, spending on the AOTC was nearly $\$ 19$ billion, comparable to annual spending on the Pell just a few years earlier. With the simultaneous increases in Pell generosity (described below), annual spending on that program in 2010 was $\$ 35$ billion in 2010 (Crandall-Hollick, 2012; College Board, 2011).

The AGI cap on the AOTC is considerably higher than that on the Hope Credit: $\$ 180,000$ for a joint return. Before AOTC, $18 \%$ of the dollars devoted to the education tax credits and deductions went to families with incomes over \$100,000; the figure for 2010 was $26 \%$ (College Board, 2011). And because the AOTC is partially refundable, expenditures for low-AGI families also increased: 
pre-AOTC $5 \%$ of the credit and tuition deduction dollars went to filers with incomes under $\$ 25,000$; in 2011 the share was $17 \%$. The AGI cap on the AOTC is higher than that on any of the other credits or deductions. High-income households that were once only eligible for the tuition tax deduction (see below) are now eligible for the more-generous AOTC. As a result, the share of households claiming the deduction has dropped while the share claiming the credits has risen.

\subsection{Tuition and Loan Interest Deductions}

Since 2002, families not claiming one of the education tax credits have been able to deduct up to $\$ 4,000$ in tuition fees from income. This is an "above-the-line" deduction that filers can use even if they do not itemize. Although the benefit officially expired at the end of 2011, it has been retroactively reinstated in the past. The benefit was originally set to expire in 2005, but in 2006 it was extended to cover 2006 and 2007; in 2008 it was extended to cover 2008 and 2009; and in 2010 it was extended to cover 2010 and 2011. For 2011, the income limit for this deduction was $\$ 80,000$ for single filers or $\$ 160,000$ for joint returns.

Up to $\$ 2,500$ in interest on student loans is deductible from taxable income for households with incomes up to $\$ 75,000$ (single) or $\$ 150,000$ (married). This deduction is for interest on any student loans, not just federal loans. This deduction was estimated to cost $\$ 1.5$ billion in tax revenue in 2010. With rapid increases in the share of middle-income families carrying student loan debt (Simon and Barry, 2012), we expect that the revenue implications of this deduction will also grow rapidly.

\subsection{Savings Incentives}

The federal Coverdell Education Savings Account and state 529 savings plans are tax-advantaged savings accounts for education. Earnings accrue untaxed in these accounts. Withdrawals are untaxed if they are used for postsecondary expenses. The Coverdell can also be used for elementary or secondary expenses; it is the only federal tax benefit for private elementary or secondary schooling. The Coverdell allows for annual, after-tax deposits of up to $\$ 2,000$. The more generous contribution limits for the 529 vary by state: cumulative contribution limits for a beneficiary range from 
$\$ 146,000$ to $\$ 305,000$. A typical state allows an annual contribution of $\$ 10,000$ for married filers (Finaid.org, 2012). The 529 accounts can be transferred to a relative.

These savings accounts were estimated to cost $\$ 1.4$ billion in tax expenditures in 2010 . The benefits of these savings accounts rise sharply with income, since those with the highest marginal tax rates benefit the most from sheltering capital income from taxation (Dynarski, 2000). These additional deductions have little to no value for low-income families, who face relatively low marginal tax rates.

\subsection{Dependent Exemption}

Children are generally considered independent for tax purposes after age 18. This is extended to age 24 if the child is enrolled in school, allowing parents to claim a dependent exemption for the student, thus reducing their taxable income. This provision also applies to the Earned Income Tax Credit, a refundable credit for low-income families. These provisions save households up to several thousand dollars a year for each child enrolled in college and were estimated to cost about $\$ 3$ billion in 2010 (U.S. Government Accountability Office, 2011).

\subsection{Evidence on the Effectiveness of the Tax Expenditures}

A simple model of human capital unambiguously predicts that subsidizing college costs raises the privately-optimal level of schooling. While the theoretical predictions are clear, it is an empirical question how much a given dollar of subsidy affects behavior.

Evidence regarding the effect of the tax benefits on educational outcomes is limited to just two studies. An early study using a difference-in-difference approach (comparing financially-eligible and ineligible families before and after the introduction of the Hope and Lifetime Learning Tax Credits) found no evidence of impacts (Long, 2004). This null effect was attributed to the credits' non-refundability (which limited its value for low-income families) and their delivery well after tuition bills are due.

A recent study uses a similar difference-in-difference strategy, but includes the new American Opportunity Tax Credit in its analysis and also takes advantage of more accurate data on income 
eligibility (Turner, 2011). This study finds effects of roughly the same magnitude as has been found for grant assistance (discussed below): the probability of college enrollment increases by 3 percentage points for every $\$ 1,000$ of tax-based aid. It is possible that earlier analysis simply could not discern an effect because some eligible families were incorrectly classified as ineligible in the data, and vice versa, attenuating the estimated difference between groups. It is also possible that the AOTC is more effective than its predecessors, since its refundability opens it to families whose decision to attend college may plausibly be constrained by income. However, the credit is still delivered well after tuition is paid, which limits its ability to solve liquidity constraints for these families.

\subsection{Challenges in Administering the Tax Credits}

The Government Accountability Office has found that many families do not choose the tax advantage that would most benefit them. Families can choose among the AOTC, LLC, tuition tax deduction, or disbursement from a 529 or Coverdell to cover current expenses. Different types of expenditures (tuition, books, living expenses) qualify for some of these but not others. GAO found that about $15 \%$ percent of filers made a suboptimal choice, suggesting substantial confusion among filers and tax preparers (U.S. Government Accountability Office, 2012).

In 2011, the Treasury Inspector General for Tax Administration (TIGTA) released a report highly critical of the administration of the AOTC (Treasury Inspector General for Tax Administration, 2011). TIGTA inspected the income tax returns that claimed in AOTC in 2009, the first year of the credit, and found ambiguities in two million returns qualifying for $\$ 3$ billion in credits. Most of these flagged returns lacked a Form 1098-T by the IRS that support students' attendance at an eligible college. The same colleges that qualify for federal financial aid qualify for the tax credits, so this reflects a failure of coordination between ED (which has a constantly-updated list of eligible institutions) and IRS (which failed to obtain it). The report pointedly referred IRS to a publicly-available dataset of institutions in the Integrated Postsecondary Education Data System.

The report also noted that institutions inconsistently fill out the 1098-T, the information return that is used to report eligible postsecondary expenses to IRS. The intent of this form is to gather 
information about a student's costs net of any scholarship aid. The TIGTA concluded that some colleges fail to net out scholarships. TIGTA also identified 350,000 cases in which a household received a credit even though the information on the 1098-T indicated they did not fulfill at least one of the eligibility criteria (at least half-time, undergraduate). The report emphasized that reducing fraud and error in the education credits will require better gathering of information from taxpayers and postsecondary institutions.

IRS defended its performance in its response in the TIGTA report, indicating that fraud was not nearly as rampant as the report implied (Treasury Inspector General for Tax Administration, 2011). In particular, IRS noted that while TIGTA report correctly noted that millions of AOTC recipients had not had their postsecondary institutions confirmed, this was due not to fraudulent filings but to weaknesses in the IRS's databases of eligible institutions, which they pledged to improve.

In response to the TIGTA report, legislation was introduced to the House to tighten administration of the AOTC. The proposed legislation would require that taxpayers list the employer identification number of a student's postsecondary institution. In theory, this should be present on the 1098-T, but apparently some institutions listed incorrectly.

None of these administrative challenges are insurmountable. The TIGTA is holding IRS to a degree of oversight that ED has maintained over colleges for decades. However, while ED has all of the necessary lists and procedures and lines of communication in place, IRS is relatively new to the student aid game. Until the agency gets its procedures into place, the opportunities for error and fraud are widened. The TIGTA report warns, however, that improving these procedures may create additional paperwork burdens for families and colleges.

\section{Traditional Federal Aid for College}

The footprint of the IRS in the funding of postsecondary students was quite small until 1998. By contrast, the US Department of Education has been funding college students since 1965. The federal programs established in the Higher Education Act of 1965 are known collectively as Title IV aid. They include the precursors to Pell Grants, Stafford Loans, and Federal Work-Study. Title 
IV aid also includes a variety of smaller programs. The discussion that follows will focus on the largest sources of Title IV aid: the Pell Grant and federal loans.

\subsection{The Pell Grant}

HEA 1965 established the Educational Opportunity Grant Program, which allocated funds directly to colleges that committed to identifying and recruiting students with "exceptional financial need" (Gladieux and Hauptman, 1995, p. 15). In 1972, the program was split into the Supplemental Educational Opportunity Grant (SEOG) program, which survives as a small program that delivers funds directly to colleges, and the Basic Educational Opportunity Grant (BEOG) program, which delivers funds directly to students. The BEOG program, renamed the Pell Grant in 1980, expanded eligibility to students attending part-time, as well as to those in vocational education or community colleges. Over the twenty years following the 1972 legislation, the number of Pell Grant recipients grew 20-fold (College Board, 2011, table 8), while college enrollment rose by just 44 percent (Institute of Education Sciences, 2010, table 197).

While there is no explicit income limit on Pell receipt, the vast majority of Pell recipients have family incomes below $\$ 50,000$, which is slightly above the median of U.S. household incomes (Bureau of the Census, 2012, table H-6). In 2008, legislation was passed that substantially increased the generosity of the program. The maximum grant was increased, and students were allowed to receive a Pell both during the academic year and summer. These changes, combined with higher college enrollments and weak economic conditions that pushed more families into Pell eligibility, drove Pell expenditures to record levels. Pell volume increased by more than 90 percent just between 2008-09 and 2010-11, with the number of recipients rising from 6.2 million to 9.1 million and the average grant among recipients increasing from $\$ 2,945$ to $\$ 3,828$ (College Board, 2011, figures 13A and 13B). Tuition prices have risen faster than inflation, however. So while the real value of the Pell rose between 1995 and 2011, its purchasing power declined from 35\% of public four-year tuition to $32 \%$ (College Board, 2011, figures 13A and 13C). 


\subsection{Federal Loans}

The Stafford Loan, the largest student loan program, dates to 1965, when the Guaranteed Student Loan was introduced. In the original program, the government paid the interest on these loans during college, loans were limited to low-income students, and loan volume was only a third of grant volume. Changes to the loan program in 1992 resulted in a sharp uptick in volume and rapid growth over the following twenty years. A new loan was created, open to all students regardless of need, called the unsubsidized Stafford Loan. While the government does not pay the interest on unsubsidized Stafford loans while students are enrolled, both subsidized and unsubsidized Stafford loans offer interest rates, forbearance protections, and flexible repayment options that make them substantially more appealing than private student loans or credit card debt. Dependent undergraduates may borrow up to $\$ 31,000$ in unsubsidized loans regardless of need. For low-income students, up to $\$ 23,000$ of that amount may be in subsidized loans (U.S. Department of Education, 2012b).

Parents are allowed to borrow up to the full cost of attendance through federal PLUS loans, regardless of need. Unlike the Stafford loans, the PLUS loans require a credit check. Payment on these loans starts immediately, and interest accrues during college. Over half of student loans initiated each year are now through the PLUS and unsubsidized Stafford loan programs (College Board, 2011, figure 3).

\subsection{Aid Application Process}

Establishing eligibility for federal aid is called "need determination." The data elements that determine "need" are collected in the FAFSA, which is required for all federal grants and loans. This form, which most students now complete on-line, is also required for many state and institutional aid programs. The FAFSA requests information about students' own income and savings, their parents' income and savings, their receipt of various other types of governmental assistance and the amounts of other income and liabilities (such as education tax credits claimed, child support paid or received, and other money received or paid on the student's behalf). ${ }^{2}$ This information is based upon the prior tax year (e.g., 2011 for students entering college in fall 2012), meaning that

\footnotetext{
${ }^{2}$ See the 2012-13 FAFSA On The Web Worksheet, http://www.fafsa.ed.gov/fotw1213/pdf/fafsaws13c.pdf.
} 
a high school student would not be able to file a FAFSA until at least January of their senior year, or after taxes are filed.

From information on the FAFSA, the U.S. Department of Education computes the expected family contribution (EFC), an estimate of how much the family can pay out of pocket for college. Need is defined as the difference between the cost of attendance (e.g., tuition, fees, books, living expenses) and this family contribution. The EFC is provided to both students and the schools to which they have applied. Before 2008, the EFC was the only information students received upon completing the FAFSA. Online applicants now also receive an estimate of their Pell eligibility. They do not receive any estimate of their eligibility for the tax credits.

In Table 2, we compare the 2011 FAFSA to its 2006 incarnation, as well as to the 1040, 1040A and 1040EZ for the 2010 tax year. The FAFSA (116 questions) is now slightly shorter than the 1040 (126 questions). In 2006, by contrast, the FAFSA was slightly longer. Dropped questions include eight pertaining to earned income credits, additional child tax credits, welfare benefits, and untaxed social security benefits, two relating to veteran benefits, four pertaining to untaxed income and income adjustments, six calculation lines, one on planned enrollment intensity and two about the colleges to which the FAFSA is being forwarded. Added questions address tax credits and allowances (four questions), dependency status (six questions), the student's high school name and location, parents' email address, dislocated-worker status, and means-tested benefits.

\subsection{Research on the Effectiveness of the Aid Programs}

Do the aid programs administered by ED affect educational attainment? There are many more studies of the effectiveness of traditional student aid than on the effectiveness of the education tax benefits. However, the quality of this empirical evidence varies considerably. Answering this empirical question is a challenge, since eligibility for subsidies is certainly not random. Rather, aid is offered to students on the basis of characteristics that have their own effect on the probability of college attendance. For example, Pell Grants flow to low-income youth. If these students are relatively unlikely to attend college, perhaps because of low levels of parental education or lowquality secondary schooling, then estimates of the effect of aid based on this source of variation in 
aid will be downwardly biased. Conversely, since many colleges use merit scholarships to attract high-achieving students, the bias on estimates of the effect of aid will, in some cases, be positive. Since many studies in this literature pool all sources of aid into a single variable, it is frequently impossible to sign the bias on a given estimate.

This omitted variables problem may be unsolvable using standard multiple regression methods. One solution is a randomized, controlled trial, in which aid amounts are randomly assigned to a pool of potential college students. ED is currently planning such an evaluation of the effect of Pell Grant on students attending short-term, training programs. In the review that follows, we focus on studies that have used experimental or quasi-experimental methods to evaluate the effect of aid. For a detailed review, see Deming and Dynarski (2009) or Dynarski and Scott-Clayton (forthcoming).

\subsubsection{Grants}

Studies that examine the Pell Grant, currently the largest source of federal grant aid, produce mixed results: Hansen (1983) and Kane (1996) found no effect of the introduction of the Pell on the college enrollment rate of low-income recent high school graduates. Seftor and Turner (2002) use a differences-in-differences framework to examine the effect of Pell Grant eligibility rules, and find that non-traditional students are about 4 percentage points more likely to attend college once they are considered eligible. Bettinger (2004) uses a regression-discontinuity approach to look at the effect of the Pell Grant on persistence using a sample of college students; his estimates are extremely sensitive to specification.

This set of findings is consistent with a story in which experience with the aid process is important: older individuals may have learned about the Pell program over time, and continuing students may learn about the program once they enroll in school. Those who have recently graduated from high school but not yet enrolled may be the least informed and least equipped to figure out the process.

Veterans educational benefits have historically been one of the largest sources of grant aid for college in the US. Multiple studies of the post-World-War-II GI Bills (Angrist, 1993; Turner and 
Bound, 2003; Bound and Turner, 2002) have found these benefits to have raised schooling levels substantially.

Dynarski (2003) examined the elimination of the federal Social Security Student Benefit (SSSB) program, using a difference-in-difference analysis. From 1965 to 1982, the Social Security Administration paid for millions of students to go to college. Under the SSSB program, the children of deceased, disabled or retired Social Security beneficiaries received monthly payments while in college. At the program's peak, 12 percent of young full-time college students were receiving these benefits. In 1981, Congress voted to eliminate the program. The elimination of the grant program reduced college attendance of the affected group by more than a third.

Several quasi-experimental studies of large state merit aid programs, which provide scholarships to students meeting minimum GPA and/or test score thresholds, have found significant positive impacts on enrollment (Dynarski, 2000, 2004; Cornwell and Mustard, 2006; Dynarski, 2008). These include regression-discontinuity studies of programs in DC, California and West Virgina (Kane, 2007; Abraham and Clark, 2006; Kane, 2003; Scott-Clayton, 2011).

\subsubsection{Loans}

There is very little rigorous research on the effect of student loans. Dynarski (2002) finds suggestive evidence of positive effects of student loan expansions in the U.S. in the early 1990s on college attendance, but the estimates are not highly robust to specification checks. A review by Heller (2008) of the effects of loans on college access concluded that the findings from the non-experimental literature can at best be described as mixed. In part, this may be because studies are inconsistent in their choice of counterfactual: they may be comparing $\$ 1$ of loans to $\$ 1$ of grants, $\$ 1$ of workstudy, or to no aid at all. Based on the non-experimental evidence, Heller concludes that college enrollments are not as sensitive to loans as to grants. This is unsurprising given that loans are not worth as much to students, but since they also cost less, it is unclear whether loans may still be cost-effective compared to grants. 


\subsubsection{The Application Process}

A recent experimental study by Bettinger et al. (2012) provides evidence that the complexity of the aid process undermines the effectiveness of aid. In this experiment, low-income families who visited a tax-preparation center were randomly assigned to one of three groups: 1) a full treatment group who received both personalized information about eligibility for financial aid as well as personal assistance with completing and submitting the FAFSA; 2) an information-only group that received personalized information about financial aid eligibility but no application assistance; and 3) a control group that received a brochure with general information about college costs, financial aid, and the value of going to college.

The full treatment, which took less than 10 minutes and cost less than $\$ 100$ per participant, increased immediate college entry rates by 8 percentage points ( 24 percent) for high school seniors and 1.5 percentage points (16 percent) among independent participants with no prior college experience. After three years, participants in the full treatment group had accumulated significantly more time in college than the control group. Impacts on Pell Grant receipt were even larger.

\section{Recent Policy Responses to Complexity in Aid}

This evidence discussed suggests that the details of aid design and delivery may be important moderators of program impacts. The programs that have clearly demonstrated positive impacts tend to have simple, easy-to-understand eligibility rules and application procedures, but the evidence regarding federal Pell Grants (the nation's largest, but comparatively opaque grant program) is surprisingly weak. The FAFSA experiment clearly demonstrated that a substantial streamlining of the aid process would substantially boost college enrollment.

In this journal in 2007, building upon Dynarski and Scott-Clayton (2006, 2007), we showed that the FAFSA rivals the IRS tax forms in length, containing more questions than the 1040EZ, 1040A or even the 1040. We also demonstrated that there is very little tradeoff between simplicity

and targeting in the federal aid programs, since the majority of questions on the FAFSA have little marginal impact on federal aid eligibility. A small handful of the questions - in particular, income 
and family size - account for over 90 percent of the variation in Pell grant eligibility. Most of the questions could therefore be removed from the FAFSA while maintaining the existing distribution of aid.

Several organizations under the direction of the federal government have also acknowledged this complexity and called on the need to reform the application process. In 2005, the Advisory Committee on Student Financial Assistance released a report examining the financial aid system and concluded

"Millions of students and adult learners who aspire to college are overwhelmed by the complexity of student aid. Uncertainty and confusion robs them of its significant benefits. Rather than promote access, student aid often creates a series of barriers a gauntlet that the poorest students must run to get to college. Replacing complexity with a steady stream of encouragement that makes access to college simple and certain is a top priority of Congress and the higher education community." (p. i)

The suggestion in the Committee's report of making the application process less complex was reiterated in the 2006 report of the Commission on the Future of Higher Education, which had been charged by then-Secretary of Education Margaret Spellings to identify challenges facing the higher education system in the United States. The Commission called for "consolidating programs, streamlining process, and replacing the FAFSA with a much shorter and simpler application" (Commission on the Future of Higher Education, 2006). In 2008, a working group of academics and aid officials released a report sounding similar themes under the auspices of the College Board (Rethinking Student Aid Study Group, 2008).

In the midst of this policy discussion, Congress approved several simplifications to the aid process in the College Cost Reduction and Access Act of 2007. These provisions did not take effect until the 2009-10 academic year. CCRAA eliminated portions of the FAFSA, including Worksheet A, which had asked about untaxed income. But CCRAA also imposed new requirements for determining if a student was an independent, thereby adding questions to the FAFSA. CCRAA also expanded the number of students who automatically qualified for a family contribution of zero (an "auto-zero EFC"). Before CCRAA, households with annual income below $\$ 20,000$ were eligible for the auto-zero; CCRAA raised that threshold to $\$ 30,000$ (U.S. Department of Education, 2008b).

Upon Barack Obama's election, the National Economic Council and the Council of Economic 
Advisers began working on efforts to streamline the aid process. In September 2009 they released a report devoted to the topic (Council of Economic Advisors, 2009) that drew extensively upon Dynarski and Scott-Clayton $(2006,2007)$ and the report of the Rethinking Student Aid Study Group (2008). During the summer of 2009, Congressional committees developed ambitious legislation to streamline the aid form. Most of these provisions were eventually discarded in last-minute negotiations that were dominated by legislation to overhaul student loans and health care.

Since this burst of Congressional activity in 2007 and 2008, the most significant changes to the aid system have been made by administrative authority. ED has worked to simplify the online FAFSA, eliminating repetitive questions (e.g., applicants had previously been asked their age and birth date in three different places) and introducing "skip logic" that allows students and parents to answer fewer questions based on their responses to screening questions (U.S. Department of Education, 2010).

In spring 2010, some online applicants were for the first time allowed to automatically transfer their IRS data into the FAFSA application. This process saves applicants from having to collect tax documents and enter items manually. This may prevent data-entry errors that cause applications to be flagged for revision and resubmission. ${ }^{3}$ This represented a major administrative breakthrough, since IRS had steadfastly refused to allow any such transfer of data to ED, citing both privacy concerns and a longstanding opposition to using tax data for any purpose other than tax collection. Both of these issues were resolved to IRS's satisfaction by having applicants personally log into IRS servers while filling in the FAFSA, with data items then copied over to the aid form via the applicant's web browser.

This effort to streamline the online application was paired with an ongoing campaign to move applicants away from the paper FAFSA. ED stopped accepting bulk orders for the paper FAFSA that had been placed annually by colleges, high schools, college coaching programs, libraries, and community agencies. This meant that students were no longer able to go to their high school guidance counselor to get a copy of the FAFSA, but had to instead order one from ED. Paper

\footnotetext{
${ }^{3} \mathrm{ED}$ has for a number of years sent FAFSAs to IRS to have them checked for errors in income and tax data. Upon discovering an inconsistency, IRS flags the application, which ED then returns to the applicant for revision. IRS does not specify (to ED or the applicant) which answer is in error.
} 
applications dropped sharply in the wake of this change in policy, from 778,000 in 2006-07 filling year to 500,000 in the following year (U.S. Department of Education, 2007b). In 2009-10, only 40,000 paper FAFSA applications were submitted (U.S. Department of Education, 2011a).

In another important development, completing the FAFSA online (but not on paper) now produces an immediate estimate of federal aid eligibility, just as completing a 1040 produces an estimate of tax liability. Previously, applicants received no notification of aid eligibility until they received a letter from the aid offices of the colleges to which they had been admitted.

\section{How Does the Aid System Look Today?}

We have just described quite a bit of activity. What has been the net effect of this activity on the applicant experience? Is the aid application process less of a hurdle than it was in 2007 ?

\subsection{Length of the FAFSA}

The FAFSA still makes the typical tax return look svelte. While two dozen questions have been removed from the FAFSA in the past five years, another dozen have been added. As a result, the FAFSA now has 116 questions, compared to 127 questions five years ago. In Table 2, we compare the 2011-12 FAFSA to its 2006-07 incarnation, as well as to the 1040, 1040A and 1040EZ for the 2010 tax year. The FAFSA is now slightly shorter than the 1040, at 116 and 126 questions, respectively. In 2006, by contrast, the FAFSA was slightly longer. Since more than half of families with incomes in the Pell range (that is, below $\$ 50,000$ ) fill out the $1040 \mathrm{~A}$ or 1040EZ, ${ }^{4}$ the shorter tax forms may be a more appropriate benchmark. The FAFSA compares poorly with these shorter IRS forms: the 1040EZ has 38 questions and the 1040A has 84, compared to the FAFSA's 116. Nine data items on the 1040EZ (44 on the 1040A) are used to compute tax liability, as compared to the 66 FAFSA questions used to compute aid eligibility. As was true in 2006, it is a puzzle why the aid system requires so much more data than the tax system to determine ability to pay.

\footnotetext{
${ }^{4}$ Authors' calculations using published tables in Parisi (2011).
} 


\subsection{Estimated Time to Complete the FAFSA}

As can be seen in Table 2, ED has increased its estimate of time needed to complete the paper FAFSA, from one hour to three hours:

"The time required to complete the paper or PDF version of the FAFSA is estimated to be three hours; the time required to complete the web version of the FAFSA, on FAFSA on the Web, is estimated to be one hour and fifteen minutes; the time required to complete the pre-filled web version of the FAFSA, on FAFSA on the Web, is estimated to be fifty-five minutes. These estimates include the time necessary to review instructions, search data resources, gather the data needed, and complete and review the information collection, and make copies of output documents for future reference." 5

The agency was roundly criticized for the implausibility of its earlier estimates, and these new estimates still seem low. By way of comparison, the IRS estimates that it takes seven hours to complete the 1040EZ, which is a third the length of the FAFSA. The IRS estimates it takes 23 hours to complete the 1040, which is only slightly longer than the FAFSA.

Outside researchers who have fielded taxpayer surveys have concluded that even these IRS estimates are low (Blumenthal and Slemrod, 1992). No independent researchers have conducted a similar survey or observation of the time required to complete the FAFSA, whether on paper or online. The Paperwork Reduction Act of 1995, which mandates these time estimates, allows each agency to choose its own method for calculating the time costs of filling out federal forms. The online FAFSA consists of 19 screens, 116 questions and many pages of accompanying instructions. ED has provided no justification or description of the time-use methodology behind its assertion that it takes 75 minutes to complete this process, including gathering the requisite documentation. ${ }^{6}$

\subsection{FAFSA-IRS Link Benefits Few Applicants}

The ability of an applicant to link data from his 1040 to his FAFSA has great potential to simplify the application process. Much of the financial data needed to compute aid eligibility is present in the IRS data, as are many of the demographic items that the FAFSA requests. As discussed in

\footnotetext{
${ }^{5}$ 2012-13 FAFSA instructions, downloaded on January 2, 2012 from http://studentaid.ed.gov.

${ }^{6}$ The Office of Management and Budget recently issued a clarification of the implementation Paperwork Reduction Act, directing agencies to conduct usability tests when creating forms; it is unclear whether this will apply to existing forms such as the FAFSA or only new ones.
} 
Dynarski and Scott-Clayton $(2006,2007)$, it is feasible to eliminate the FAFSA completely, using a check-off on the 1040 to indicate that a person is applying for aid.

As implemented, however, the IRS link falls well short of this potential. Applicants are allowed to import their IRS data only if they have already filed their tax return for the previous tax

year. IRS says it needs an additional two to eight weeks to make returns available to online aid applicants. As a result, it is virtually impossible for anyone filing under the traditional academic and tax schedules to use the FAFSA-IRS link. A family who files a 1040 as soon as W-2s are due in household mailboxes (start of February) would be eligible to use the FAFSA-IRS link sometime between mid-February and April, while a family who files on tax day would not be able to do so until May or June. These dates are after the FAFSA deadlines imposed by most colleges, as well as the FAFSA deadlines for virtually every state aid program. Even by mid-April, the date by which our early-bird tax filer could plausibly use the FAFSA-IRS link, the filing deadline has passed for fifteen state aid programs, including those in California (March 2) and Illinois ("as soon as possible after January 1").

Students who want to qualify for state aid need to file even earlier than these posted deadlines, since some programs give out funds on a first-come, first-served basis, with eligible candidates left empty-handed if funds run dry before they file. In an analysis of Kentucky's College Access Program Grant, we found that roughly 40 percent of eligible applicants received no grant because funds ran out before the filing deadline. A student who wants to maximize her chances of receiving aid would therefore file early, forgo the IRS match and manually enter her tax information. And this, indeed, is what has occurred. ED estimates that just 24 percent of applicants use the IRS link (U.S. Department of Education, 2011b).

\section{Prospects for Simplification}

With the growth in the education tax credits in recent years, we now have two federal agencies administering and delivering aid for college students. ED has done this for decades, and has a fairly smooth process in place for communicating with colleges and delivering funds to students through those colleges. Treasury, by contrast, is fairly new to this game and there have been growing pains. 
The current structure of overlapping responsibilities represents an inefficient use of resources. Asking ED to develop expertise in gathering and verifying families' income data is similarly inefficient, since IRS already does this work in order to administer the federal tax system The competencies of the two agencies are complementary, and an efficiently designed system of postsecondary subsidies could be built upon the strengths of the two agencies.

In particular, IRS could continue to gather the household data that determines individual eligibility for the tax credits and aid, ceding to ED the work of delivering aid and communicating with colleges. This division of labor would build on the relative strengths of the two agencies while reducing the paperwork burden imposed on households and colleges. Paperwork would be most reduced if ED used only IRS data in its calculation of aid eligibility. This represents a substantial shortening of the number of data items that would be used in calculating aid eligibility.

\subsection{Feasibility of Streamlining the Aid System}

We have described the evolution of complexity in the aid system and recent efforts to reduce it. What are the possibilities going forward? Dynarski and Scott-Clayton (2006) showed, based on 2003-04 data, that the aid system could be massively simplified without compromising targeting in the Pell program. Does this finding still hold? In this section we update the analysis of Dynarski and Scott-Clayton (2006) using 2007-08 data on student aid and aid applications. ${ }^{7}$

We show that the vast majority of questions still have little impact on aid eligibility and could be eliminated with very little effect on the distribution of aid. We also examine the effect of using older tax data in the calculation of aid. If ED were willing to use the previous year's tax return to calculate aid eligibility, then all applicants could take advantage of the IRS-FAFSA link, thereby considerably streamlining the application process.

We focus on Pell Grants, since they are the most expensive component of federal need-based aid. Note that the tax benefits are already distributed based only on IRS data items, so this exercise is unnecessary for the AOTC. The question at hand is whether we could use IRS data to define eligibility for aid, just as we do for the credits, thereby getting ED out of the business of gathering

\footnotetext{
${ }^{7}$ We use data from the 2007-08 National Postsecondary Student Aid Survey (NPSAS:08).
} 
income data from households.

\subsection{Example: Removing Assets from the Aid Calculation}

An example will demonstrate our approach. The FAFSA gathers information on applicants' assets. These enter into the calculation of a family's Expected Family Contribution (EFC). Housing equity and funds in tax-advantaged retirement accounts are not considered in the calculation of the EFC and are therefore not collected by the FAFSA. Since IRS does not collect information about asset holdings, this information would be lost were aid eligibility to be calculated using only IRS data. What would be the impact on the distribution of aid if assets were ignored? A subset of (marginal) families will have their aid eligibility changed if assets are ignored. Other (intra-marginal) families will see no change, because their other financial characteristics either place them firmly beyond the margin of aid eligibility or at the aid maximum.

Figure 1 shows our estimated distribution of the Pell Grant, by income, during the 2007-08 academic year. We calculate these Pell Grants using the federal financial aid formula and all of the relevant information in the FAFSA. ${ }^{8}$ In this graph, each income category contains $5 \%$ of the sample. The average Pell Grant drops sharply with income, and is essentially zero above incomes of about $\$ 60,000$.

What happens if we drop assets from the calculation of Pell eligibility? To answer this question, we set all assets to zero, and recalculate aid eligibility. Nobody's Pell eligibility will go down in this scenario, since no one is needier when assets are ignored. The share of FAFSA applicants eligible for a Pell (52\%) does not change, while the average Pell Grant rises from $\$ 1,320$ to $\$ 1,344$ (Table 3). Total Pell spending for this population rises from $\$ 12.0$ to $\$ 12.1$ billion. For $95 \%$ of aid applicants, there is zero change in the Pell amount for which they are eligible. That is, for only $5 \%$ of aid aid applicants is there any relationship between asset holdings and Pell eligibility. For 97\% of aid applicants, Pell eligibility changes by less than $\$ 100$.

The resulting changes to the distribution of Pell are shown in Figure 1, to which we have already

\footnotetext{
${ }^{8}$ When we compare these calculated aid amounts to their true values (which are contained in NPSAS), we come extremely close to the true values: regressing the actual against the predicted values yields an $\mathrm{R}^{2}$ of 0.96 for the EFC and 0.998 for the Pell. See Data Appendix.
} 
referred. The dark shading is the change in the Pell Grant induced by ignoring assets. The change is not easy to see in this graph, because it is so small.

The EFC is the aid program's summary statistic for ability to pay. It is used for calculating not only the Pell Grant, but also subsidized student loans, state aid, and non-government aid offered by colleges. While dropping assets affects the Pell eligibility of only $6 \%$ of applicants, it affects the EFC of $30 \%$ (Table 3). For $12 \%$ of applicants, in fact, the EFC drops by more than $\$ 500$. How can this be consistent with the small impact on Pell just discussed? Baseline EFC ranges from zero to $\$ 100,000$ in our sample. Dropping assets alters the EFC substantially for applicants almost exclusively in the upper ranges, as shown in Figure 2A, which plots the new against old EFCs, along with the 45-degree line. We also plot the 25th and 75th percentiles of the cells. Each cell contains $1 \%$ of the sample.

Note that all of the observations are below the 45-degree line: dropping assets can only reduce the estimated family contribution. Also note the tight clustering near the origin, with the vast majority of EFCs below $\$ 30,000$ (Figure 2B focuses on this subsample). There are a few large changes depicted in Figure 2A. For example, for the top $1 \%$ of EFCs (the rightmost point) the average EFC drops by more than $\$ 10,000$, while in the next lowest cell it drops by $\$ 5,000$. The average EFCs in these cells at baseline are $\$ 70,000$ and $\$ 50,000$, respectively. Dropping assets brings the average EFC for these cells down to $\$ 60,000$ and $\$ 45,000$, respectively. These values are above the cost of full-time attendance at the vast majority of colleges. No federal or state aid is awarded to families with EFCs in this range, so variation in this range is irrelevant for these programs. $^{9}$

One concern is that families with substantial assets but low incomes don't currently apply for aid, since they know they will be disqualified on the basis of their assets. These families would not appear in our data, which consists only of aid applicants. To check this, we examine asset and income data in the 2007 Survey of Consumer Finances, to see if there is a substantial population of

\footnotetext{
${ }^{9}$ Conceivably, a family with two children simultaneously enrolled at an expensive four-year college could qualify for grants from a wealthy institution such as Harvard or Yale even with an EFC of $\$ 45,000$. These schools may therefore choose to gather more information than would be provided by the FAFSA - and in fact, already do. Both schools already require that parents complete the College Board PROFILE, which collects items not requested in the FAFSA (e.g., home equity, retirement funds).
} 
families with low incomes but large asset holdings. Among families with children in the Pell income range (less than $\$ 40,000), 96 \%$ have less than $\$ 150,000$ in non-retirement, non-housing assets.

\subsection{Implications of Relying Upon IRS Data to Define Aid Eligibility}

We concentrated on assets in the section above because it has been the focus of the most intense scrutiny in discussions of aid simplification. We will not repeat this full exercise for every data element in the FAFSA, because there are 66 financial items that go into the formula. Rather, we will show the effect of eliminating from the aid calculation all of the non-IRS data items. This includes data items whose elimination would tend to make families look needier (e.g., assets) as well as those whose elimination would tend to make families look better off (e.g., medical expenses). We show the net effect of eliminating all of these data items on the EFC and Pell.

We next examine how aid changes when only IRS data is used to determine eligibility. This opens the door to an application-free Pell, since eligibility could be calculated using IRS data alone. With this approach, we determine Pell amounts using the adjusted gross income of the parents and students, taxes paid, state of residence, family size, parents' and independent students' marital status, and the type of income tax form filed. We also make use of the number of family members in college and receipt of a means-tested benefit.

\subsubsection{Shifts in the Distribution of Pell As A Result of Simplification}

The correlation between the baseline Pell and the Pell based on the limited set of variable is 0.95 (Table 3). The extensive data we drop in this simulation explain only nine percent of the variation in aid (Column (3), Table 3). With the few variables we include, we explain 90.9 percent of the variation in the Pell Grant. For 74 percent of FAFSA applicants the Pell does not change by even a dollar. Our simulated Pell is within $\$ 100$ of the baseline Pell (which we estimated using all of the items in the aid formula) for 80 percent of students, and within $\$ 500$ of baseline for 91 percent of students. Of the remaining $9 \%$, two-thirds (6\%) gain more than $\$ 500$ while a third $(3 \%)$ lose more than $\$ 500$ relative to the current regime. The share of students eligible for Pell Grants rises from $52 \%$ to $53 \%$. The average Pell increases from $\$ 1,320$ to $\$ 1,379$, or about $4.4 \%$. Pell spending rises 
from $\$ 12$ billion to $\$ 12.52$ billion.

Note that this approach uses the existing formula but simply zeroes out all of the elements that are not present in the tax data. An alternative approach would be to rewrite the formula, assigning weights to the various IRS data items that replicate the current distribution of aid.

The changes in the distribution of the Pell resulting from this massive simplification of the aid form are depicted in Figure 3, where we plot average Pell against adjusted gross income. Independent and dependent students are pooled in these data. Each income interval represents 5 percent of the sample. The light bars depict the average Pell for each income group, using the complete aid formula. The dark bars represent the change in the average Pell for each income group that results from using only IRS data to estimate aid eligibility. As is clear from the figure, the changes are extremely small. The increases are largely among families with incomes between $\$ 24,000$ and $\$ 38,000$. The average Pell for this population rises by $\$ 59$ from a baseline of $\$ 1,320$, or 4.5\%. We estimate that overall Pell spending would rise by about $\$ 500$ million for this population.

\subsubsection{How Large Are These Implied Shifts in the Distribution of Pell?}

These projected shifts in the distribution of aid induced by simplification are dwarfed by recent policy changes that have increased the generosity of the Pell. The Pell maximum was raised from $\$ 4,310$ in 2007 to $\$ 5,510$ in 2011 . Further, many more students were automatically assigned an EFC of zero based on their low incomes; the maximum income for a auto-zero EFC was raised from $\$ 15,000$ in 2003 to $\$ 31,000$ in 2012 . When a student is assigned an auto-EFC, all of the financial information in the FAFSA is essentially thrown out.

The impact of the recent increases in Pell generosity on the distribution of Pell are depicted in Figure 4 and Table 5. For these calculations, we take aid applicants in the 2007-08 NPSAS and run their characteristics through the aid formulas for academic years 2007-08 and 2011-12. This analysis effectively holds constant student characteristics (income, schooling costs, etc.) while

allowing the aid formula to vary. The average Pell for this population rises from $\$ 1,320$ in 2007 to $\$ 2,127$ in 2011 (Table 5). The share of applicants eligible for the Pell rises from $48 \%$ to $63 \%$. Pell expenditures for this population rise by more than half, from $\$ 12$ billion to $\$ 19.3$ billion. These 
increases largely accrued to families in the middle of the Pell range - the same applicants who would see much more modest increases from simplification (Figure 4).

\subsubsection{What About Programs Other than Pell?}

We have shown that determining aid eligibility using IRS data alone has little impact on the Pell. But what about other aid programs, which may be a function of a greater range of values of the EFC than is the Pell? To address this question, we repeat the analysis just discussed, with the EFC as the variable of interest (Table 3). Eliminating all of the non-IRS questions induces an increase in the average EFC of about $3 \%$, from $\$ 8,078$ to $\$ 8,344$.

While $91 \%$ of applicants remain within $\$ 500$ of their baseline Pell with a simplified formula, only $72 \%$ of the simplified EFCs are within this range of their baseline. For $19 \%$ of applicants, the EFC rises by more than $\$ 500$ while for $9 \%$ of applicants the EFC drops by more than $\$ 500$. EFC has a much broader range, going as high as $\$ 100,000$ in our sample. Figure 5 depicts the changes in the distribution of the EFC induced by simplification. The bars indicate the 25th and 75th percentiles of the simplified EFC for each of 100 cells, which each represent $1 \%$ of the sample. The cells generally lie along the 45-degree line, indicating average changes of zero within these cells. The wide bars indicate that these zero averages are generated by large positive and negative shifts in EFC.

Note, however, that these large shifts occur solely at very high EFCs, which apply to relatively few families. A student with an EFC above $\$ 5,000$ will not receive a Pell. But what about other forms of aid? Several state aid programs have effective EFC ceilings below that of the Pell (e.g., Texas and Ohio). Simplifying the formula would have little impact on the size of the population eligible for those programs. The cutoffs for other state programs are higher: Illinois, for example, has an EFC cutoff of $\$ 9,000$ for its grant program, while students with an EFC up to $\$ 12,000$ qualify for Minnesota's program. If anything, in this range we see that EFCs under a simplified formula tend to be slightly higher in this range. This analysis suggest that more students would not be swept into eligibility for the state aid programs by simplification. 


\subsubsection{Use Older IRS Data to Calculate Aid Eligibility}

All applicants, rather than just 24 percent, could benefit from the FAFSA-IRS link if the requirement were lifted that the applicant had already filed their 1040 for the previous tax year. One option is that the FAFSA-IRS link could provide data from the previous year's 1040. That is, a student applying in early 2012 for aid for 2012-13 could use IRS data from tax year 2010 (rather than 2011) to complete her FAFSA. These data could either be used to determine her final aid eligibility, or as a placeholder until the 1040 is filed for 2011. The latter is effectively what happens now: most applicants will complete their 2012-13 FAFSA before filing their 2011 taxes, providing estimates of their 2011 tax data in their FAFSA application. They are then required to update their FAFSA once they file for the 2011 tax year.

As it stands, however, families manually enter these estimates. ED could instead import from IRS the 2010 tax data as an estimate of the 2011 data. Applicants who are confident that their 2011 tax data will differ substantially from the 2010 values can choose to manually enter their information. As they do now, families would then receive an estimate of their aid eligibility based on the 2010 data. ED and IRS could automatically update these values when the 2011 tax form is filed, just as the individual applicant now does. While these may sound like minor administrative tweaks, these minor tweaks open the possibility of a nearly-automatic aid application. As Kahneman and Tversky (2000) and Thaler and Sunstein (2008) argue, small differences in administrative requirements can produce enormous differences in outcomes.

This approach still leaves some uncertainty in final aid eligibility (though no more than currently exists), since aid may be changed once the 2011 tax form is filed. An alternative that would allow for both simplicity and certainty in the aid process would be to determine final aid eligibility based on the previous year's 1040. As we now show, this has little impact on the targeting of aid while increasing its simplicity and certainty.

For this analysis, we need to observe income in two consecutive years for a set of students. About half of the students in NPSAS who apply for aid for the 2007-08 academic year do so the following year (2008-09). These students are likely a select subset of the population, but look comparable to the full sample (see Appendix Table). We estimate 2008-09 aid amounts using the 
methodology described earlier, first using all of the elements in the aid formula and then just the subset of items available in the IRS data. We then replace the IRS data items that were reported on the 2008-09 FAFSA with those reported on the 2007-08 FAFSA. This simulates the effect of allowing 2008-09 applicants to use data from the 1040 they filed in 2007 (for the 2006 tax year), rather than using the 1040 they will file in 2008 (for the 2007 tax year).

Table 4 shows the results. For this sample of repeat applicants (as was true for the full sample), restricting the aid formula to IRS data has little effect on aid eligibility (Column 3), with 72 percent of applicants seeing zero change in their Pell eligibility and 88 percent seeing a change of less than $\$ 500$. When we replace this IRS data with data from one year earlier, the results change slightly (Column 4), with 64 percent of applicants seeing zero change in their Pell eligibility and 75 percent seeing a change of less than $\$ 500$. The average Pell for this group rises by $\$ 96$, from a baseline value of $\$ 1,615$ (Column 1), or 4.8 percent.

\section{Conclusion}

There are now a dozen tax expenditures for education, representing $\$ 29$ billion in forgone revenue annually. Traditional aid for college students, in the form of grants and loans, represents an additional $\$ 150$ billion. With the rapid growth of the tax credits, an increasing number of students now complete paperwork for both the IRS and the US Department of Education in order to obtain college funding.

We now have compelling evidence that complexity in the aid system undermines its effectiveness. Yet in the past five years we have seen only halting progress in simplifying the aid system, with one question added to the FAFSA for every two removed. And there is more paperwork on the horizon for families and colleges, with the Treasury Inspector General putting pressure on the IRS to obtain more documentation from applicants and colleges regarding their eligibility for the tax credits. If carried through, these steps will largely duplicate the work that ED already does in administering the traditional aid programs and multiply paperwork burdens on households and colleges.

ED and IRS bring complementary strengths to the administration of aid for college. ED has long experience in delivering aid to students and communicating with colleges. IRS has a well- 
developed capacity for gathering and verifying income data from households. Conversely, IRS has little experience with verifying student enrollment and delivering aid when it is needed. And while ED has long experience in gathering income data from applicants, it does so by imposing substantial paperwork burdens upon households and colleges. Just one example: colleges are statutorily required to "verify" a minimum of $30 \%$ of their aid applications each year, an auditing process that requires applicants to submit extra supporting documentation, including copies of tax returns. Some colleges audit $100 \%$ of their aid applications. Were tax data alone used to calculate aid eligibility, the data underlying all applications would automatically be verified, since it would come from the IRS rather than the applicant.

At a minimum, a simpler aid program would increase the efficiency of aid dollars by reducing the administrative and paperwork costs for schools and families. At best, simplification would clarify incentives for students and induce into college some who now believe it is unaffordable.

\section{Data Appendix}

\subsection{Data and Sample}

We use individual-level data from the restricted-use version of the 2007-08 National Postsecondary Student Aid Survey (NPSAS:08). NPSAS:08 is representative of students filing for aid for the 2007-08 school year. About half the sample also files a FAFSA for the 2008-09 school year, and we examine only this sample in some of our analyses.

The NPSAS:08 includes FAFSA and financial aid data for 75,710 (11,199,083 survey-weighted) undergraduate federal aid applicants. We drop students who enroll in more than one college during an academic year, because their complete cost of attendance is not available. This reduces the sample from 75,710 to 64,500 (10,223,034 survey-weighted). We drop an additional 1,480 (289,809 survey-weighted) students who were missing either EFC or data elements needed to calculate EFC. 


\subsection{Calculating EFC and Pell Eligibility}

We calculate students' EFC and Pell eligibility using the FAFSA items contained in NPSAS and the 2007-08 or 2008-09 aid formulas, as documented in the Federal Student Aid Handbook by the U.S. Department of Education (2007a, 2008a). We compare these calculated amounts to their actual values, which are also provided in NPSAS. Since enrollment information that goes into calculating the Pell for part-time students is not consistently provided in NPSAS, and also because NPSAS perturbs a small percentage of cases in order to maintain confidentiality, we do expect our calculated aid amounts to perfectly match the actual amounts. However, we come quite close. For only $5 \%$ of the sample (3,780 observations) are we off by more than $\$ 4,000$ in our Pell calculations. Most of these cases are students whom we calculate to be Pell eligible but do not receive any Pell grant, or whom we calculate are not eligible for any Pell but do receive a Pell. Since these students' Pells are not replicable using even all of the information in NPSAS, we drop them from the analysis.

This leaves us an analytic sample of 59,240 (9,083,492 survey-weighted) undergraduate aid applicants for 2007-08. For this sample, our calculated aid amounts are extremely close to their actual values. Regressing the actual against the calculated $2007-08$ values yields an $\mathrm{R}^{2}$ of 0.958 for the EFC and 0.998 for the Pell. We use the calculated values in all of the simulations in which we drop items from the aid formula.

About half of this analytic sample filed a FAFSA for both the 2007-08 and 2008-09 academic years. For analysis in which we examine the reliability of older income data for estimating aid, we dropped 2,870 (28,5670 survey-weighted) students who changed their Title-IV defined dependency status between filing years. This yields a sample of $27,540(4,757,248$ survey-weighted $)$ students for these analyses.

Weighted sample statistics are in Appendix Table A2. In the first column is the full analytic sample, while the second column is limited to those students who apply for aid two years in a row. A little over half of the sample is dependent under Title IV rules, $19 \%$ are independents with no dependents and $25 \%$ are independents with dependents. Over $60 \%$ of the students are female. Two-thirds attend college full-time for at least part of the year, while the balance are never enrolled more than half time. A third attend public, four-year colleges, 30\% attend community colleges, $19 \%$ 
attend private, non-profit schools, while $17 \%$ attend for-profit schools. $52 \%$ of applicants receive a Pell Grant.

\subsection{Part-Time Students' EFC and Pell Eligibility}

NPSAS does not provide all of the information required to calculate Pell eligibility for students enrolled part-time. Students who attend full-time for the entire year are eligible for the full Pell, while all other students are eligible for a percentage of that full Pell.This percentage depends on which of four categories of enrollment intensity the student falls into each term: full-time, threequarter time, half-time and less than half-time. Unfortunately, this information is not provided on a term-by-term basis in NPSAS. We estimate enrollment intensity by dividing a student's actual Pell by the Pell we calculate them to be eligible for were they enrolled full-time for the full year. The resulting distribution of estimated enrollment intensities looks sensible, with students clustered around permutations of the four categories of enrollment intensity (e.g., 75\%, 87.5\%). We use these estimated enrollment intensities in our simulations. 


\section{References}

Abraham, Katharine G. and Melissa A. Clark, "Financial Aid and Students' College Decisions: Evidence from the District of Columbia Tuition Assistance Grant Program," The Journal of Human Resources, July 2006, 41 (3), 578-610.

Ackerman, Deena, Julie-Anne Cronin, Nick Turner, and Andrew Bershadker, "Coordinating the American Opportunity Tax Credit and The Federal Pell Grant," November 2011. Unpublished.

Advisory Committee on Student Financial Assistance, The Student Aid Gauntlet: Making Access to College Simple and Certain, Washington, DC: Advisory Committee on Student Financial Assistance, January 2005.

Angrist, Joshua D., "The Effect of Veterans' Benefits on Education and Earnings," Industrial and Labor Relations Review, 1993, 46 (4), 637-652.

Bettinger, Eric P., "How Financial Aid Affects Persistence," in Caroline Hoxby, ed., College Choices: The Economics of Where to Go, When to Go, and How to Pay for It, University of Chicago Press, 2004.

_, Bridget Terry Long, Philip Oreopoulos, and Lisa Sanbonmatsu, "The Role of Application Assistance and Information in College Decisions: Results from the H\&R Block FAFSA Experiment," The Quarterly Journal of Economics, 2012, 127 (3), 1205-1242.

Blumenthal, Marshal and Joel Slemrod, "The Compliance Cost of the U.S Individual Income Tax System: A Second Look After Tax Reform," National Tax Journal, 1992, 2, 185-202.

Bound, John and Sarah Turner, "Going to War and Going to College: Did World War II and the G.I. Bill Increase Educational Attainment for Returning Veterans?," Journal of Labor Economics, October 2002, 20 (4), 784-815.

Bureau of the Census, "Regions All Races by Median and Mean Income 1975-2010," www. census.gov/hhes/www/income/data/historical/household/2010/H06AR_2010.xls 2012 . 
College Board, Trends in Student Aid: 2011, Washington, DC: College Board, 2011.

Commission on the Future of Higher Education, A Test of Leadership: Charting the Future of U.S. Higher Education, Washington, DC: U.S. Department of Education, 2006.

Cornwell, Christopher M. and David Mustard, "The Enrollment Effects of Merit-Based Financial Aid; Evidence from Georgia's HOPE Program," Journal of Labor Economics, 2006, 24 (4), 761-86.

Council of Economic Advisors, Simplifying Student Aid: The Case for an Easier, Faster, and More Accurate FAFSA, Washington, DC: Council of Economic Advisers, 2009.

Crandall-Hollick, Margot L., "The American Opportunity Tax Credit: Overview, Analysis, and Policy Options," CRS Report for Congress R42561, Congressional Research Service, Washington, DC June 2012.

Deming, David and Susan Dynarski, "Into College, Out of Poverty? Policies to Increase the Postsecondary Attainment of the Poor," National Bureau of Economic Research Working Paper Series, September 2009, No. $1538 \%$.

Department of the Treasury, Internal Revenue Service, "Publication 970: Tax Benefits for Education," Technical Report 2011.

Dynarski, Susan, "Hope for Whom? Financial Aid for the Middle Class and Its Impact on College Attendance," National Tax Journal, September 2000, 53 (3), 629-661.

_ , "Loans, Liquidity, and Schooling Decisions," Manuscript, Harvard University Kennedy School of Government, Boston, MA 2002.

_ , "Does Aid Matter? Measuring the Effect of Student Aid on College Attendance and Completion," American Economic Review, 2003, 93 (1), 279-288.

_ , "Who Benefits from the Education Saving Incentives? Income, Educational Expectations, and the Value of the 529 and Coverdell," Technical Report, National Bureau of Economic Research, Inc May 2004. 
_ , "Building the Stock of College-Educated Labor," Journal of Human Resources, 2008, 43 (3), $576-610$.

_ and Judith Scott-Clayton, "The Cost of Complexity in Federal Student Aid: Lessons from Optimal Tax Theory and Behavioral Economics," National Tax Journal, 2006, 59 (2), 319-356.

_ and _ , "Pell Grants on a Postcard: A Proposal for Simple and Predictable Federal Student Aid," Discussion Paper 2007-01, The Hamilton Project, Washington, DC February 2007.

_ and _ , "Complexity and Targeting in Federal Student Aid: A Quantitative Analysis," Tax Policy and the Economy, 2008, 22, 109-150.

_ and _ , "Financial Aid: Research Lessons for a Changing Policy Landscape," The Future of Children, forthcoming.

- and Mark Wiederspan, "Student Aid Simplification: Looking Back and Looking Ahead," National Tax Journal, 2012, 65 (1), 211-234.

Finaid.org, "FinAid: Saving for College: Section 529 Plans," www.finaid.org/savings/ 529plans.phtml\#Contributions 2012.

Gladieux, Lawrence and Arthur M. Hauptman, The College Aid Quandary: Access, Quality, and the Federal Role, Washington, DC: The Brookings Institution, 1995.

Hansen, W. Lee, "Impact of Student Financial Aid on Access," Proceedings of the Academy of Political Science, 1983, 35 (2), 84-96.

Hearn, James C., "The Paradox of Growth in Federal Aid for College Students, 1965-1990," in Michael B. Paulsen and John C. Smart, eds., The Finance of Higher Education: Theory, Research, Policy and Practice, New York, NY: Agathon Press, 2001, pp. 267-320.

Heller, Donald E., "The Impact of Student Loans on College Access," in Sandy Baum, Michael S. McPherson, and Patricia Steele, eds., The Effectiveness of Student Aid Policies: What the Research Tells Us, New York, NY: College Board, 2008, pp. 39-67. 
Institute of Education Sciences, Digest of Education Statistics: 2009, Washington, DC: U.S. Department of Education, 2010.

_ , Digest of Education Statistics: 2011, Washington, DC: U.S. Department of Education, 2011.

Kahneman, Daniel and Amos Tversky, Choices, Values and Frames, Cambridge, MA: Cambridge University Press, 2000.

Kane, Thomas J., "Lessons From the Largest School Voucher Program Ever: Two Decades of Experience with Pell Grants," in Bruce Fuller, Richard Elmore, and Gary Orfield, eds., Who Chooses? Who Loses? Culture, Institutions and the Unequal Effects of School CHoice, New York, NY: Teachers College Press, 1996.

_ , "Student Aid after Tax Reform: Risks and Opportunities," in Jacqueline E. King, ed., Financing a College Education: How It Works, How It's Changing, Phoenix, AZ: The American Council on Education and Oryx Press, 1999, pp. 137-150.

_ , "A Quasi-Experimental Estimate of the Impact of Financial Aid on College-Going," Technical Report, National Bureau of Economic Research, Inc May 2003.

_ , "Evaluating the Impact of the D.C. Tuition Assistance Grant Program," The Journal of Human Resources, July 2007, 42 (3), 555-582.

Long, Bridget T., "The Impact of Federal Tax Credits for Higher Education Expenses," in Caroline Hoxby, ed., College Choices: The Economics of Where to Go, When to Go, and How to Pay for It, Chicago, IL: University of Chicago Press, 2004.

Madrian, Brigitte C. and Dennis F. Shea, "The Power of Suggestion: Inertia in 401(k) Participation and Savings Behavior," Quarterly Journal of Economics, November 2001, 116 (4), $1149-1187$.

Moynihan, Daniel Patrick, "Why Private Schools Merit Public Aid: The Constitutional Case for Tuition Tax Credits," 1978. Address to the National Association of Independent Schools Annual Conference in New York. 
Parisi, Michael, "Individual Income Tax Returns, Preliminary Data, 2009," Statistics of Income Bulletin, Winter 2011.

Rethinking Student Aid Study Group, Fulfilling the Commitment: Recommendations for Reforming Federal Student Aid, Washington, DC: College Board, 2008.

Scott-Clayton, Judith, "On Money and Motivation," Journal of Human Resources, 2011, 46 (3), 614-646.

Seftor, Neil S. and Sarah E. Turner, "Back to School: Federal Student Aid Policy and Adult College Enrollment," The Journal of Human Resources, April 2002, 37 (2), 336-352. ArticleType: research-article / Full publication date: Spring, 2002 / Copyright 2002 The Board of Regents of the University of Wisconsin System.

Silliman, Benjamin Rue, "College Tuition Tax Credits: An Examination of the Impact of the American Opportunity, HOPE, and Lifetime Learning Tax Credits Since 1998," in Jake Zhu and Wali I. Mondal, eds., Proceedings of American Soceity of Business and Behavioral Sciences, Vol. 18 2011, pp. 279-288.

Simon, Ruth and Rob Barry, "College Debt Hits Well-Off — Upper-Middle-Income Households See Biggest Jumps in Student Loan Burden,” Aug 092012.

Thaler, Richard and Cass. Sunstein, Nudge: Improving Decisions About Health, Wealth, and Happiness, Yale University Press, 2008.

Treasury Inspector General for Tax Administration, "Billions of Dollars in Education Credits Appear to Be Erroneous," Technical Report, Treasury Inspector General for Tax Administration, Washington, DC September 2011.

Turner, Nicholas, "The Effect of Tax-Based Federal Student Aid On College Enrollment," $N a$ tional Tax Journal, 2011, 64 (3), 839-862. 
Turner, Sarah and John Bound, "Closing the Gap or Widening the Divide: The Effects of the G.I. Bill and World War II on the Educational Outcomes of Black Americans," The Journal of Economic History, March 2003, 63 (01).

U.S. Department of Education, 2007-2008 Federal Student Aid Handbook, Washington, DC: U.S. Department of Education, 2007.

_, Summary of Changes for the Application Processing System: 2008-2009, Washington, DC: U.S. Department of Education, 2007.

_, 2008-2009 Federal Student Aid Handbook, Washington, DC: U.S. Department of Education, 2008.

_, Summary of Changes for the Application Processing System: 2009-2010, Washington, DC: U.S. Department of Education, 2008.

_ , Summary of Changes for the Application Processing System: 2011-2012, Washington, DC: U.S. Department of Education, 2010.

_, 2009-2010 Federal Pell Grant Program End-of-Year Report, Washington, DC: U.S. Department of Education, 2011.

_ , "Federal Student Aid Applicant: Facts and Figures," Technical Report, Washington, DC 2011. _, 2010-2011 Federal Pell Grant Program End-of-Year Report, Washington, DC: U.S. Department of Education, 2012.

_, "Subsidized and Unsubsidized Loans," http://studentaid.ed.gov/types/loans/ subsidized-unsubsidized\#how-much-can-i-borrow 2012.

U.S. Government Accountability Office, "Fiscal Year 2012, Analytical Perspectives, Budget of the U.S. Government," Technical Report, U.S. Government Accountability Office, Washington, DC 2011. 
_ , "Higher Education: Improved Tax Information Could Help Families Pay for College," Report to the Committee on Finance, U.S. Senate GAO-12-560, U.S. Government Accountability Office, Washington, DC May 2012. 


\section{Table 1}

Federal Support for Postsecondary Students by Source, 2010

\begin{tabular}{lr}
\hline & Amount \\
& (\$billions) \\
\hline Grants & $\mathbf{\$ 4 9 . 0 6}$ \\
Pell & $\$ 34.76$ \\
Veterans/Military & $\$ 12.15$ \\
Supplemental Educational Opportunity & $\$ 0.76$ \\
Academic Competitiveness & $\$ 0.55$ \\
Other & $\$ 0.40$ \\
SMART & $\$ 0.38$ \\
LEAP & $\$ 0.06$ \\
& \\
Loans & $\$ \mathbf{1 0 3 . 9 9}$ \\
Unsubsidized Stafford & $\$ 46.09$ \\
Subsidized Stafford & $\$ 39.69$ \\
PLUS & $\$ 17.11$ \\
Perkins & $\$ 0.97$ \\
Other & $\$ 0.13$ \\
Work-Study & $\$ \mathbf{1 . 1 7}$ \\
Tax Credits/Deductions/Exclusions & \\
American Opportunity Tax Credit & $\$ \mathbf{2 8 . 6 5}$ \\
Lifetime Learning Tax Credit & $\$ 15.11$ \\
Dependent exemption for students aged 19-23 & $\$ 3.49$ \\
Exclusion of scholarship and fellowship income & $\$ 2.96$ \\
Deductibility of student-loan interest & $\$ 2.76$ \\
Exclusion of asset earnings in 529 plans & $\$ 1.48$ \\
Deduction for higher education expenses & $\$ 1.39$ \\
Exclusion of employer-provided grants & $\$ 0.76$ \\
Exclusion of interest on savings bonds & $\$ 0.68$ \\
Total Federal Support & $\$ 0.02$ \\
& $\$ \mathbf{1 8 2 . 8 8}$ \\
\hline & \\
\hline
\end{tabular}

Notes: Table adapted from Ackerman, et al. (2011). Education Tax Credit/Deductions/Exclusion data from Table 17-2, U.S. Office of Management and Budget (2011). Financial aid data from Table 1, College Board (2011). All values in 2010 constant dollars. Financial aid data for 2010-11 are preliminary estimates. 
Table 2

IRS versus FAFSA Question Counts

\begin{tabular}{|c|c|c|c|c|c|}
\hline & $\begin{array}{l}1040 \\
2010\end{array}$ & $\begin{array}{c}1040 \mathrm{~A} \\
2010 \\
\end{array}$ & $\begin{array}{l}1040 \mathrm{EZ} \\
2010 \\
\end{array}$ & $\begin{array}{c}\text { FAFSA } \\
2006-2007 \\
\end{array}$ & $\begin{array}{c}\text { FAFSA } \\
2011-2012 \\
\end{array}$ \\
\hline Number of pages (excluding instructions) & 2 & 2 & 1 & 5 & 6 \\
\hline $\begin{array}{l}\text { Number of questions } \\
\text { Answered through IRS data transfer }\end{array}$ & 126 & 84 & 38 & 127 & $\begin{array}{c}116 \\
18\end{array}$ \\
\hline $\begin{array}{l}\text { Non-financial items } \\
\text { Identifying information } \\
\text { Demographic/family information } \\
\text { Enrollment status/school } \\
\text { Signature and preparer } \\
\text { Other }\end{array}$ & $\begin{array}{c}6 \\
8 \\
0 \\
12 \\
1\end{array}$ & $\begin{array}{c}6 \\
8 \\
0 \\
12 \\
1\end{array}$ & $\begin{array}{c}6 \\
2 \\
0 \\
12 \\
1\end{array}$ & $\begin{array}{c}22 \\
18 \\
7 \\
8 \\
10\end{array}$ & $\begin{array}{c}24 \\
29 \\
4 \\
8 \\
7\end{array}$ \\
\hline $\begin{array}{l}\text { Financial items } \\
\text { Earned income } \\
\text { Other income } \\
\text { Assets } \\
\text { Deductions/credits/allowances } \\
\text { Calculations from tables } \\
\text { Withholdings, refund preferences }\end{array}$ & $\begin{array}{c}1 \\
19 \\
0 \\
42 \\
21 \\
16\end{array}$ & $\begin{array}{c}1 \\
12 \\
0 \\
23 \\
12 \\
9\end{array}$ & $\begin{array}{l}1 \\
2 \\
0 \\
3 \\
6 \\
5\end{array}$ & $\begin{array}{c}5 \\
33 \\
6 \\
12 \\
6 \\
0\end{array}$ & $\begin{array}{c}5 \\
19 \\
6 \\
14 \\
0 \\
0\end{array}$ \\
\hline $\begin{array}{l}\text { Number of items required for computation } \\
\text { of tax/refund or aid amount }\end{array}$ & 76 & 44 & 9 & 72 & 66 \\
\hline Number of words in signing statement & 49 & 64 & 59 & 232 & 232 \\
\hline $\begin{array}{l}\text { Official estimate of hours to prepare } \\
\text { Paper } \\
\text { Web }\end{array}$ & 23 & 9 & 7 & 1 & $\begin{array}{l}3 \\
1\end{array}$ \\
\hline
\end{tabular}

Notes: Counts for the FAFSA are for dependent students with two parents and include questions on required student and parent worksheets. Total number of questions includes sub-questions and non-numbered questions. Items such as name and address are counted in the same way on IRS and FAFSA forms. 
Table 3

Effect of Aid Formula Simplification on Pell Grants and Expected Family Contribution

\begin{tabular}{|c|c|c|c|}
\hline & $\begin{array}{c}2007-08 \\
\text { Full FAFSA } \\
\text { (1) } \\
\end{array}$ & $\begin{array}{l}\text { 2007-08 } \\
\text { Dropping } \\
\text { Assets } \\
(2)\end{array}$ & $\begin{array}{c}\text { 2007-08 } \\
\text { IRS Data Only } \\
\text { (3) }\end{array}$ \\
\hline \multicolumn{4}{|l|}{ Panel A: Pell Grant } \\
\hline Correlation between new and old Pell & 1.00 & 0.992 & 0.953 \\
\hline $\mathrm{R}^{2}$ & 1.00 & 0.983 & 0.909 \\
\hline \multicolumn{4}{|l|}{ Percent of applicants whose Pell } \\
\hline ...does not change & 1.00 & 0.95 & 0.74 \\
\hline ...is within $\$ 100$ of baseline & 1.00 & 0.97 & 0.80 \\
\hline$\ldots$ is within $\$ 500$ of baseline & 1.00 & 0.99 & 0.91 \\
\hline ...increases by $\$ 500$ or more & & 0.01 & 0.06 \\
\hline ...decreases by $\$ 500$ or more & & 0.00 & 0.03 \\
\hline Average Pell grant (includes zeroes) (\$) & 1,320 & 1,344 & 1,379 \\
\hline Total Pell grants (\$billion) & 11.99 & 12.21 & 12.52 \\
\hline Share receiving Pell Grants & 0.52 & 0.52 & 0.53 \\
\hline \multicolumn{4}{|l|}{ Panel B: Expected Family Contribution } \\
\hline Correlation between new and old EFC & 1.00 & 0.98 & 0.95 \\
\hline $\mathrm{R}^{2}$ & 1.00 & 0.96 & 0.90 \\
\hline \multicolumn{4}{|l|}{ Percent of applicants whose EFC } \\
\hline ...does not change & 1.00 & 0.70 & 0.28 \\
\hline ...is within $\$ 100$ of baseline & 1.00 & 0.80 & 0.33 \\
\hline$\ldots$ is within $\$ 500$ of baseline & 1.00 & 0.88 & 0.50 \\
\hline ...increases by $\$ 500$ or more & & 0.00 & 0.34 \\
\hline ...decreases by $\$ 500$ or more & & 0.12 & 0.17 \\
\hline Average Expected Family Contribution (\$) & 8,078 & 7,472 & 8,344 \\
\hline
\end{tabular}

Notes: The sample consists of 59,240 undergraduate aid applicants enrolled at one institution during the 2007-2008 academic year. See Data Appendix for details. The analysis uses NPSAS weights (WTA000).

Source: NPSAS:08 
Table 4

Using Older Income Data to Determine EFC and Pell Grant Eligibility Estimates of 2008-09 Formula Using IRS Data from 2007 versus 2006

\begin{tabular}{|c|c|c|c|c|}
\hline & $\begin{array}{c}\text { Full FAFSA } \\
2007 \\
\text { Tax Data } \\
(1)\end{array}$ & $\begin{array}{c}\text { Full FAFSA } \\
2006 \\
\text { Tax Data } \\
(2) \\
\end{array}$ & $\begin{array}{c}\text { No FAFSA } \\
2007 \\
\text { Tax Data } \\
\text { (3) }\end{array}$ & $\begin{array}{c}\text { No FAFSA } \\
2006 \\
\text { Tax Data } \\
\text { (4) }\end{array}$ \\
\hline \multicolumn{5}{|l|}{ Panel A: Pell Grant } \\
\hline Correlation between new and old Pell & 1.00 & 0.862 & 0.953 & 0.844 \\
\hline $\mathrm{R}^{2}$ & 1.00 & 0.743 & 0.908 & 0.713 \\
\hline \multicolumn{5}{|l|}{ Percent of applicants whose Pell } \\
\hline ...does not change & 1.00 & 0.66 & 0.72 & 0.64 \\
\hline ...is within $\$ 100$ of baseline & 1.00 & 0.69 & 0.77 & 0.67 \\
\hline ...is within $\$ 500$ of baseline & 1.00 & 0.78 & 0.88 & 0.75 \\
\hline ...increases by $\$ 500$ or more & & 0.13 & 0.06 & 0.15 \\
\hline ...decreases by $\$ 500$ or more & & 0.09 & 0.05 & 0.10 \\
\hline Average Pell grant (includes zeroes) (\$) & 1,615 & 1,673 & 1,648 & 1,711 \\
\hline Total Pell grants (\$billion) & 7.68 & 7.96 & 7.84 & 8.14 \\
\hline Share receiving Pell Grants & 0.52 & 0.53 & 0.52 & 0.54 \\
\hline \multicolumn{5}{|l|}{ Panel B: Expected Family Contribution } \\
\hline Correlation between new and old EFC & 1.00 & 0.91 & 0.95 & 0.85 \\
\hline $\mathrm{R}^{2}$ & 1.00 & 0.83 & 0.90 & 0.73 \\
\hline \multicolumn{5}{|l|}{ Percent of applicants whose EFC } \\
\hline ...does not change & 1.00 & 0.24 & 0.26 & 0.23 \\
\hline ...is within $\$ 100$ of baseline & 1.00 & 0.28 & 0.31 & 0.26 \\
\hline ...is within $\$ 500$ of baseline & 1.00 & 0.41 & 0.47 & 0.36 \\
\hline ...increases by $\$ 500$ or more & & 0.24 & 0.37 & 0.32 \\
\hline ...decreases by $\$ 500$ or more & & 0.35 & 0.16 & 0.31 \\
\hline Average Expected Family Contribution (\$) & 8,289 & 7,824 & 8,716 & 8,157 \\
\hline
\end{tabular}

Notes: The sample consists of 27,540 aid applicants who filed a FAFSA in both 2007-2008 and 2008-09. See Data Appendix for details. The simulation in Column 2 uses the same elements as Column 1 but uses 2006 instead of 2007 tax information (AGI, earned income, taxes paid, type of income tax form used). The simulations in Columns 3 and 4 drop the FAFSA and use only IRS data for the listed tax years. All 2006 tax values are inflated to 2007 values using the Consumer Price Index for All Urban Consumers (CPI-U). The analysis uses NPSAS weights (WTA000).

Source: NPSAS:08 
Table 5

How Aid Formula Changes Have Affected Targeting of Pell Grant Predicted Values for 2007-2008 Undergraduate Aid Applicants

\begin{tabular}{|c|c|c|}
\hline & $\begin{array}{c}\frac{2007-08}{\text { Baseline }} \\
\text { (1) }\end{array}$ & 2011-12 \\
\hline Correlation with baseline Pell grant & 1.000 & 0.923 \\
\hline $\mathrm{R}^{2}$ & 1.000 & 0.852 \\
\hline \multicolumn{3}{|l|}{ Share of applicants whose Pell grant } \\
\hline ...is within $\$ 100$ of baseline & 1.00 & 0.39 \\
\hline ...is within $\$ 500$ of baseline & 1.00 & 0.44 \\
\hline ...increases by $\$ 500$ or more & 0.00 & 0.56 \\
\hline ...decreases by $\$ 500$ or more & 0.00 & 0.00 \\
\hline Share with automatic zero EFC & 0.19 & 0.26 \\
\hline Average Pell grant (includes zeroes) (\$) & 1,320 & 2,127 \\
\hline Total Pell grants (\$billion) & 11.99 & 19.32 \\
\hline Share Pell grant recipients & 0.52 & 0.63 \\
\hline Pell maximum $(\$)$ & 4,310 & 5,550 \\
\hline
\end{tabular}

Notes: The sample consists of 59,240 undergraduate aid applicants enrolled at one institution for the full or part year during the 2007-2008 academic year. Students' characteristics are run through the aid formula for listed years to predict aid values. See Data Appendix for details. The analysis uses NPSAS weights (WTA000).

Source: NPSAS:08 
Figure 1

Effect of Dropping Asset Related Questions from FAFSA: 2007-08 Aid Year

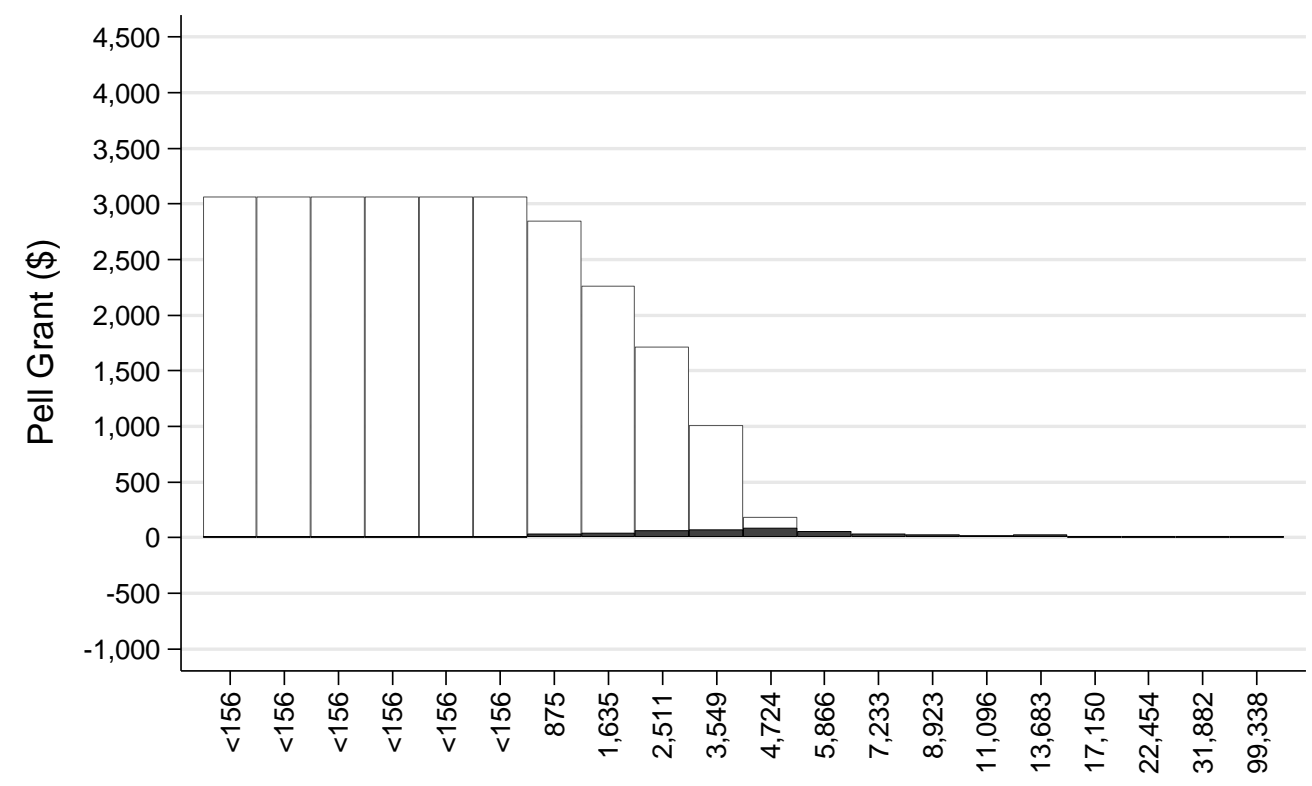

Expected Family Contribution (\$), 2007-08 Formula

Simulated Change

Notes: See notes to Table 3. 
Figure 2A

Plotting New EFC Against Old EFC: 2007-08 Aid Year Dropping Assets

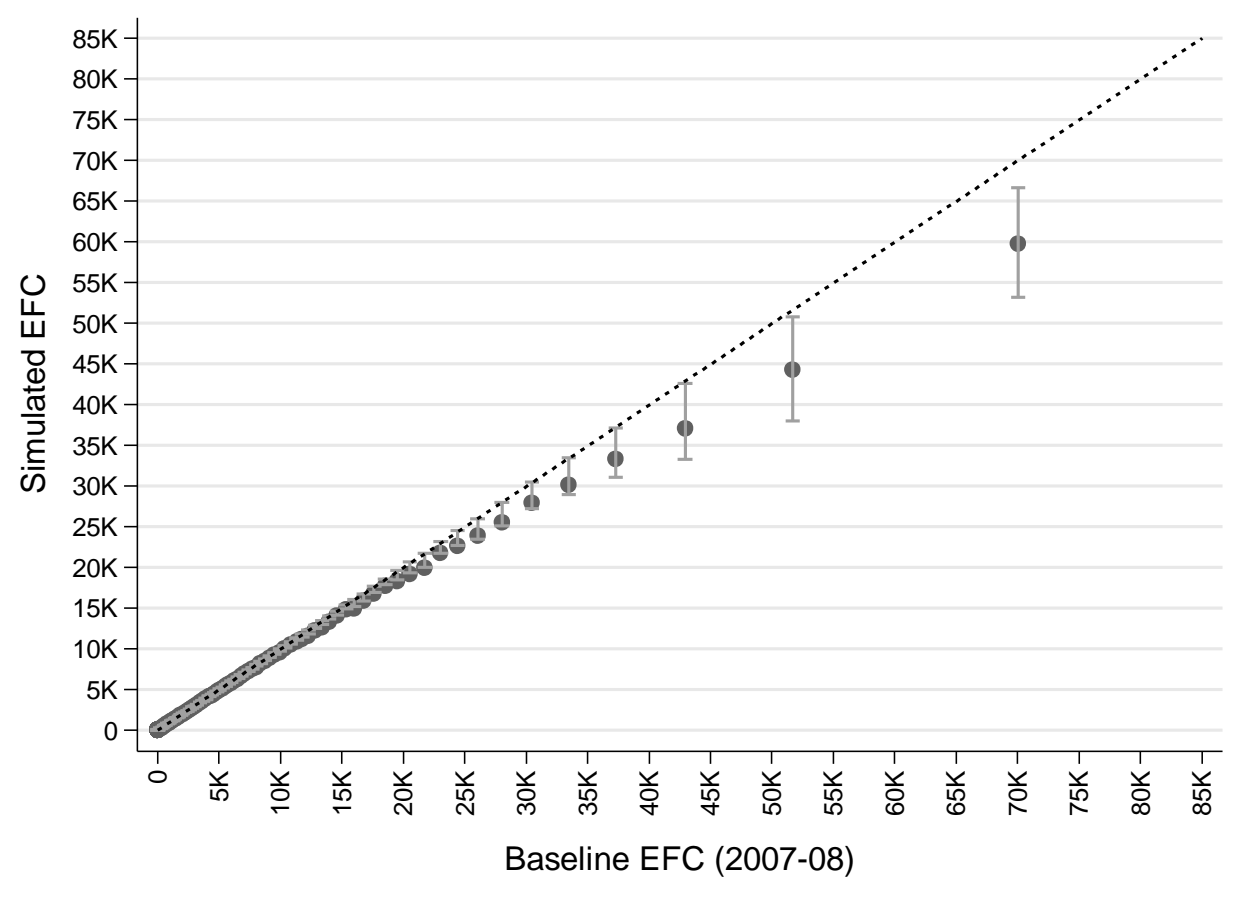

Notes: See notes to Table 3. 
Figure 2B

Plotting New EFC Against Old EFC: 2007-08 Aid Year Dropping Assets

Baseline EFC $<\$ 30,000$

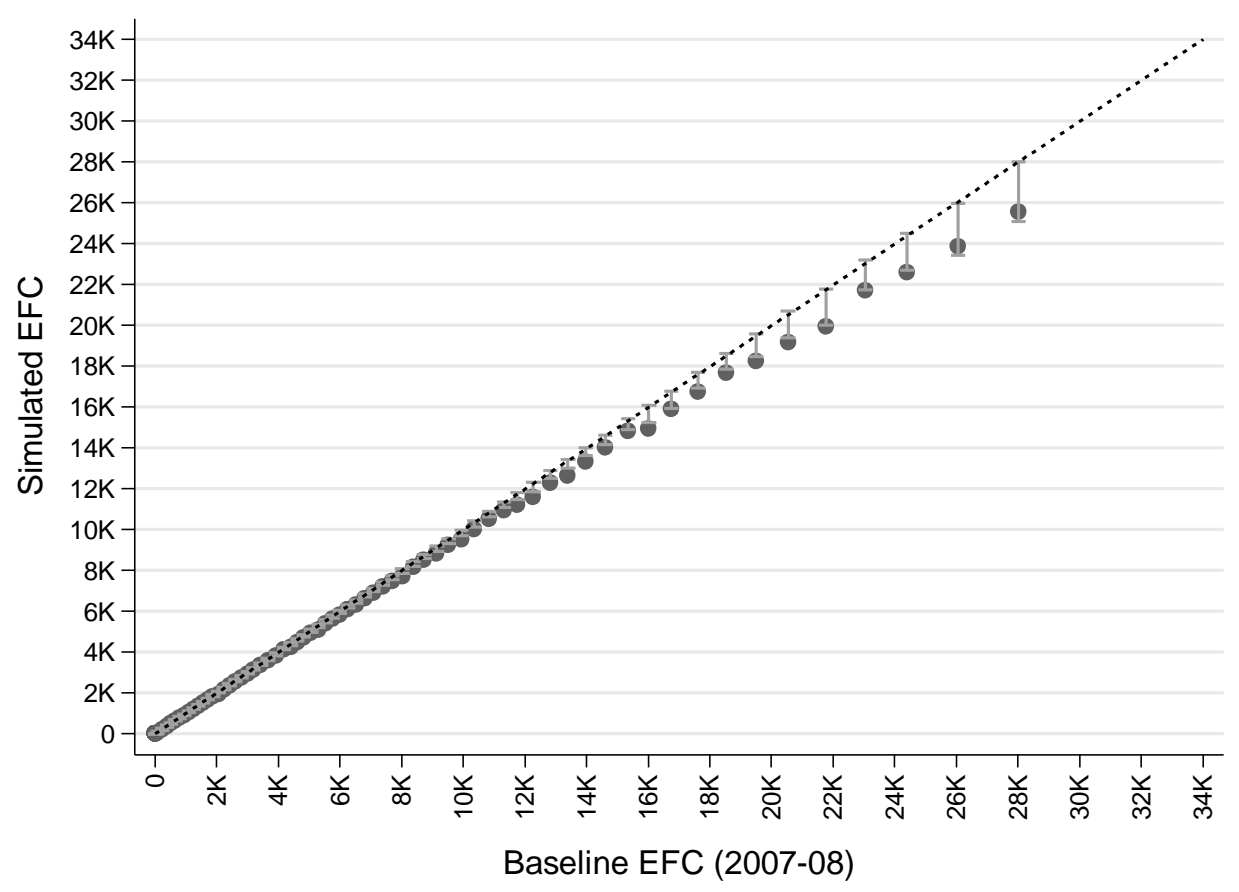

Notes: See notes to Table 3. 
Figure 3

Effect of Using Only IRS Data to Define Pell Grant Eligibility: 2007-2008 Aid Year

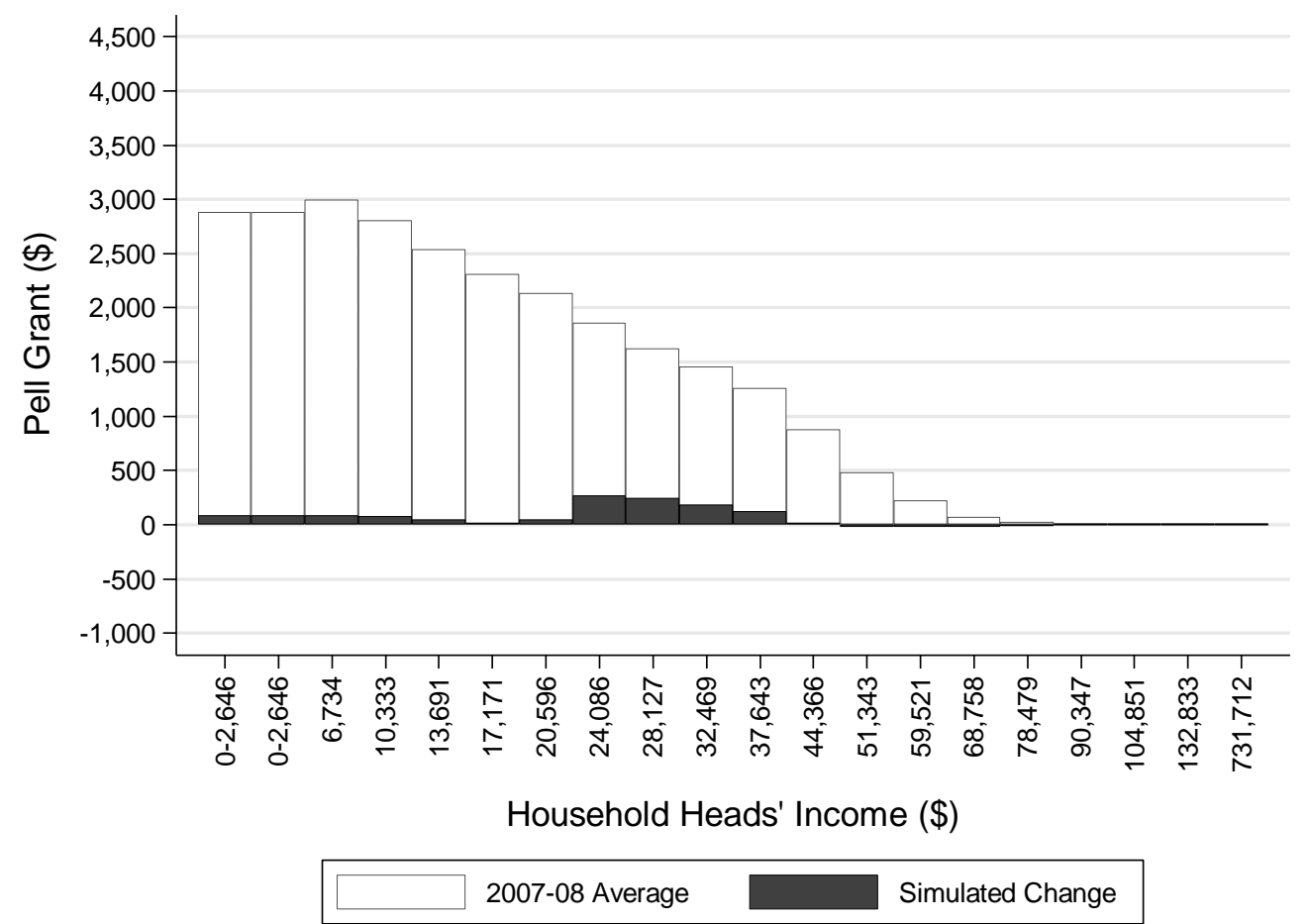

Notes: See notes to Table 3. 
Figure 4

Increases in Generosity of the Pell Grant Program from 2007-08 to 2011-12, by Income

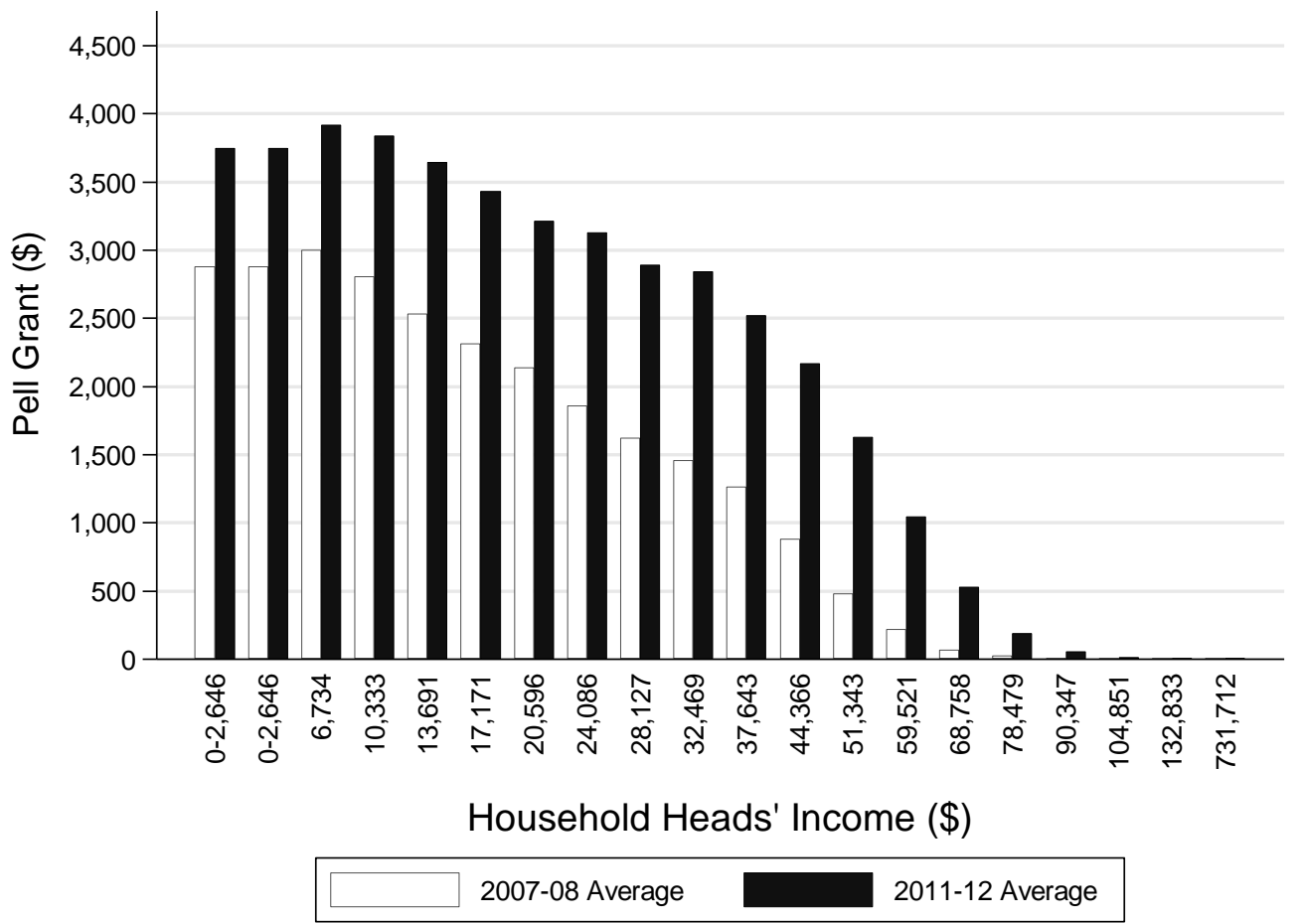

Notes: See notes to Table 5. 
Figure 5

Plotting New EFC Against Old EFC: 2007-08 Aid Year IRS Data Only

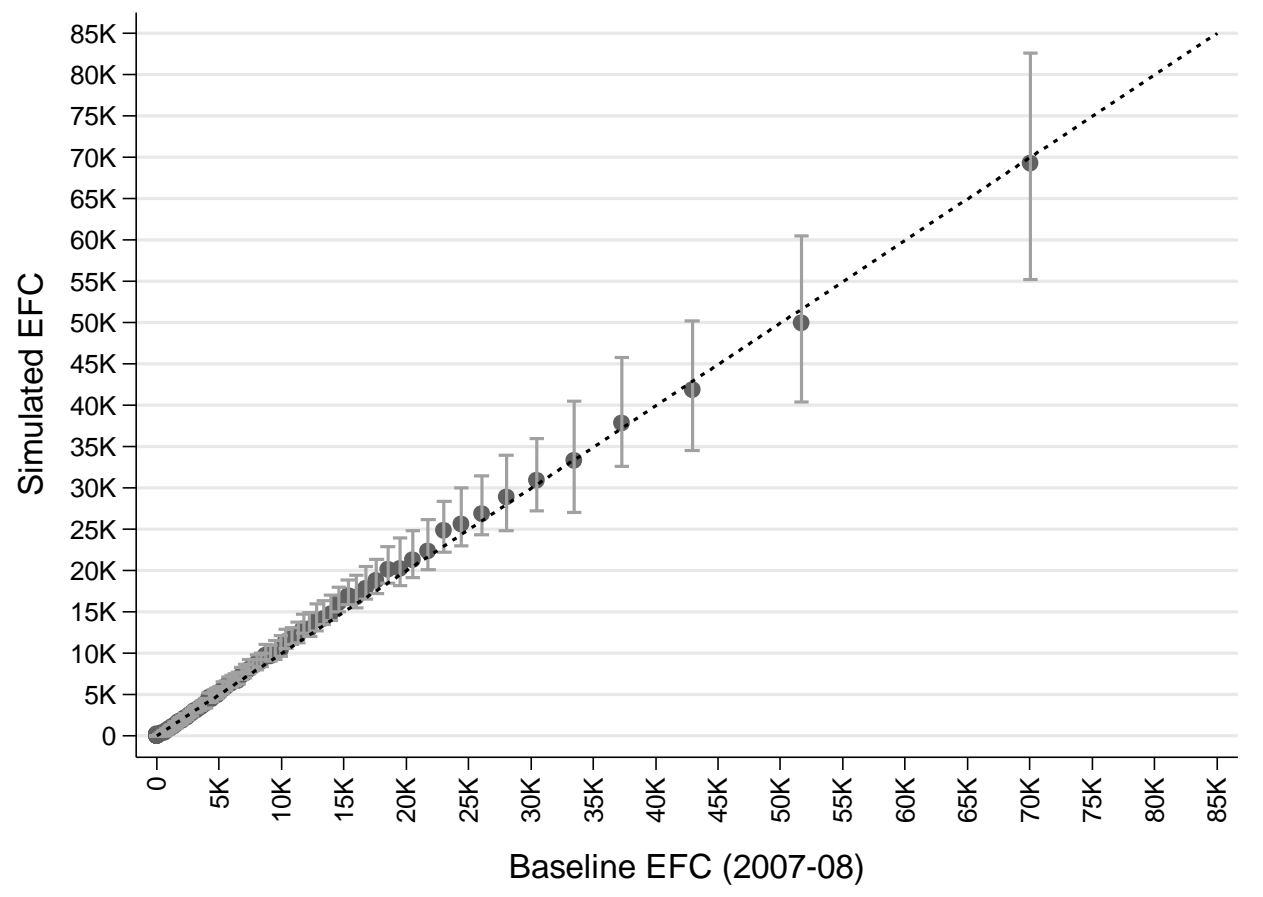

Notes: See notes to Table 3. 


\begin{tabular}{|c|c|}
\hline \multicolumn{2}{|c|}{$\begin{array}{l}\text { Appendix Table A1 } \\
\text { Description of Federal Programs for Postsecondary Students }\end{array}$} \\
\hline \multicolumn{2}{|c|}{ Federal Student Aid Programs } \\
\hline Pell Grant & $\begin{array}{l}\text { The largest funded need-based aid program in the United States. } \\
\text { Currently, students can receive a grant amount up to } \$ 5,500 \text {. The size } \\
\text { of the Pell award depends primarily upon family income and } \\
\text { enrollment intensity. }\end{array}$ \\
\hline $\begin{array}{l}\text { Unsubsidized \& } \\
\text { Subsidized Stafford } \\
\text { Loans }\end{array}$ & $\begin{array}{l}\text { Subsidized and unsubsidized loans, also known as Stafford Loans, are } \\
\text { administered by the federal government through the Federal Direct } \\
\text { Loan Program (FDLP). Unsubsidized loans are available to all students } \\
\text { regardless of need. With subsidized loans, eligibility is based on need } \\
\text { and the federal government pays the interest on these loans while the } \\
\text { student is in college. The maximum amount a dependent student can } \\
\text { borrow for an undergraduate degree under the Stafford Loan programs } \\
\text { is currently } \$ 31,000 \text {. }\end{array}$ \\
\hline \multicolumn{2}{|r|}{ Federal Tax Credits and Deductions } \\
\hline Hope Credit & $\begin{array}{l}\text { Provided a maximum credit of } \$ 1,800 \text { for qualifying expenses relating } \\
\text { to tuition and fees, only for students in their first two years of college, } \\
\text { and only for families with tax liability. The American Opportunity Tax } \\
\text { Credit replaced the Hope credit in } 2009 \text {. }\end{array}$ \\
\hline $\begin{array}{l}\text { Lifetime Learning } \\
\text { Credit (LLC) }\end{array}$ & $\begin{array}{l}\text { Eligible tax filers are able to receive a maximum credit of } \$ 2,000 \text { for } \\
\text { tuition and fees expenses. }\end{array}$ \\
\hline $\begin{array}{l}\text { American Opportunity } \\
\text { Tax Credit (AOTC) }\end{array}$ & $\begin{array}{l}\text { AOTC replaced the Hope the credit in } 2009 \text { and allows for a credit up } \\
\text { to } \$ 2,500 \text { for expenses relating to tuition and fees and course materials. } \\
\text { The credit rate is } 100 \text { percent for the first } \$ 2,000 \text { of expenses and } 25 \\
\text { percent on the next } \$ 2,000 \text {. Up to } \$ 1,000 \text { of the credit is refundable for } \\
\text { families with limited or no tax liability. }\end{array}$ \\
\hline $\begin{array}{l}\text { Tuition \& Loan } \\
\text { Interest Deductions }\end{array}$ & $\begin{array}{l}\text { These deductions offer filers a maximum deduction of } \$ 4,000 \text { for } \\
\text { expenses relating to tuition and fees. This deduction expired in } 2011 \text {, } \\
\text { but it has been retroactively reinstated after a temporary expiration } \\
\text { several times previously. }\end{array}$ \\
\hline Saving Incentives & $\begin{array}{l}\text { Interest accumulates tax-free when families save for college using } \\
\text { Federal Coverdell accounts and state } 529 \text { savings plans. Withdrawals } \\
\text { from these accounts are not taxed unless the amount withdrawn is } \\
\text { greater than the student's education expenses. }\end{array}$ \\
\hline Dependent Exemption & $\begin{array}{l}\text { A parent or guardian has the ability to claim an exemption for a } \\
\text { dependent who is between the ages } 19 \text { and } 23 \text { and is a full-time student. } \\
\text { The filer is allowed an exemption of } \$ 3,650 \text { per dependent. }\end{array}$ \\
\hline
\end{tabular}

Source: U.S. Government Accountability Office (2012) 
Appendix Table A2

Descriptive Statistics of Sample Used in Analysis

\begin{tabular}{|c|c|c|c|}
\hline \multirow{2}{*}{ 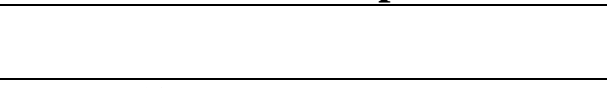 } & \multirow{2}{*}{$\begin{array}{r}\text { Full Sample } \\
2007-08 \\
\end{array}$} & \multicolumn{2}{|c|}{ Applied in Both Years } \\
\hline & & $2007-08$ & $2008-09$ \\
\hline \multicolumn{4}{|l|}{ Demographics (Average) } \\
\hline Age & 24.63 & 24.28 & 25.28 \\
\hline \multicolumn{4}{|l|}{ Gender (Share of applicants) } \\
\hline Male & 0.38 & 0.37 & 0.37 \\
\hline Female & 0.62 & 0.63 & 0.63 \\
\hline \multicolumn{4}{|l|}{ Race/Ethnicity (Share of applicants) } \\
\hline White & 0.58 & 0.59 & 0.59 \\
\hline African-American & 0.17 & 0.17 & 0.17 \\
\hline Hispanic & 0.16 & 0.15 & 0.15 \\
\hline Other Race & 0.04 & 0.04 & 0.04 \\
\hline \multicolumn{4}{|l|}{ Institutional Type (Share of applicants) } \\
\hline Public-4yr & 0.34 & 0.38 & 0.38 \\
\hline Private, Non-Profit & 0.19 & 0.21 & 0.21 \\
\hline Public-2yr & 0.30 & 0.28 & 0.28 \\
\hline Private, For-Profit & 0.17 & 0.12 & 0.12 \\
\hline \multicolumn{4}{|l|}{ Enrollment Status (Share of applicants) } \\
\hline Full-Time, Full/Part Year & 0.67 & 0.71 & 0.71 \\
\hline Part-Time, Full/Part Year & 0.33 & 0.29 & 0.29 \\
\hline \multicolumn{4}{|l|}{ Financial Aid Awards \& COA (Average) $(\$)$} \\
\hline Actual Pell Award (includes zeroes) & 1,323 & 1,468 & N/A \\
\hline Share Receiving Pell Grant & 0.52 & 0.53 & N/A \\
\hline Actual Subsidized Loan (includes zeroes) & 1,823 & 2,018 & N/A \\
\hline Share Receiving Subsidized Loan & 0.59 & 0.57 & N/A \\
\hline Actual Unsubsidized Loan (includes zeroes) & 1,297 & 1,355 & N/A \\
\hline Share Receiving Unsubsidized Loan & 0.42 & 0.40 & N/A \\
\hline Cost of Attendance & 17,242 & 18,468 & N/A \\
\hline \multicolumn{4}{|l|}{ FAFSA Elements (Average) $(\$)$} \\
\hline Automatic Zero EFC (Share of applicants) & 0.19 & 0.18 & 0.17 \\
\hline SNT (Share of applicants) & 0.48 & 0.46 & 0.45 \\
\hline Actual EFC & 8,262 & 7,827 & 8,412 \\
\hline Parents' Income $^{1}$ & 66,854 & 66,921 & 68,671 \\
\hline Parents' Taxes Paid ${ }^{1}$ & 6,045 & 5,783 & 6,196 \\
\hline Parents' Worksheet $\mathrm{A}^{1}$ & 1,526 & 1,408 & 1,257 \\
\hline Parents' Worksheet $\mathrm{B}^{1}$ & 3,732 & 3,861 & 3,793 \\
\hline Parents' Worksheet $C^{1}$ & 551 & 647 & 581 \\
\hline Parents' Cash, Savings, Checking $^{1}$ & 7,173 & 7,340 & 7,113 \\
\hline Parents' Investment Net Worth ${ }^{1}$ & 21,597 & 20,782 & 20,548 \\
\hline Parents' Business/Farm Net Worth ${ }^{1}$ & 3,766 & 3,424 & 4,110 \\
\hline Student's (\& Spouse's) Income & 13,040 & 12,147 & 13,048 \\
\hline Student's Taxes Paid & 557 & 486 & 535 \\
\hline Student's Worksheet A & 717 & 710 & 644 \\
\hline Student's Worksheet B & 577 & 571 & 517 \\
\hline Student's Worksheet C & 261 & 263 & 298 \\
\hline Student's Cash, Savings, Checking & 805 & 755 & 747 \\
\hline Student's Investment Net Worth & 995 & 846 & 837 \\
\hline Student's Business/Farm Net Worth & 55 & 53 & 65 \\
\hline \multicolumn{4}{|l|}{ Dependency Status (Share of applicants) } \\
\hline Dependents & 0.56 & 0.57 & 0.57 \\
\hline Independents w/o dependents & 0.19 & 0.18 & 0.17 \\
\hline Independents w/ dependents & 0.25 & 0.25 & 0.26 \\
\hline$N$ & 59,240 & 27,540 & 27,540 \\
\hline \multicolumn{4}{|c|}{$\begin{array}{l}\text { Notes: Column } 1 \text { represents the sample of the } 59,240 \text { aid applicants who filed a FAFSA in 2007-08. Column } \\
2 \text { represents the sample of the } 25,540 \text { aid applicants who filed a FAFSA in 2007-08 and 2008-09. The } \\
\text { analysis uses NPSAS weights (WTA000). } \\
\text { Source: NPSAS:08 } \\
{ }^{1} \text { Parents' income, tax, and assets information is specific to the } 32,890 \text { applicants who are dependent. }\end{array}$} \\
\hline
\end{tabular}

